\title{
Oregon Geology - Parent of the Soil, Foundation for the Vine
}

By Ray Wells ${ }^{1}$

Open File Report 2006-1069

Any use of trade, firm, or product names is for descriptive purposes only and does not imply endorsement by the U.S. Government.

U.S. DEPARTMENT OF THE INTERIOR

U.S. GEOLOGICAL SURVEY

${ }^{1}$ Menlo Park, Calif. 


\section{Oregon Geology - Parent of the Soil, Foundation for the Vine}

\section{Ray Wells}

US Geological Survey, 345 Middlefield Rd. MS 973, Menlo Park, CA, 94025

Project Chief, Pacific Northwest Urban Corridor Geologic Mapping Project Website: http://geology.wr.usgs.gov/wgmt/pacnw

Cooperators - Alan Campbell, Chemeketa Community College, Salem, Oregon Dave Johnson, Natural Resources Conservation Service, Salem, Oregon 


\section{Here we are on the leading edge...}

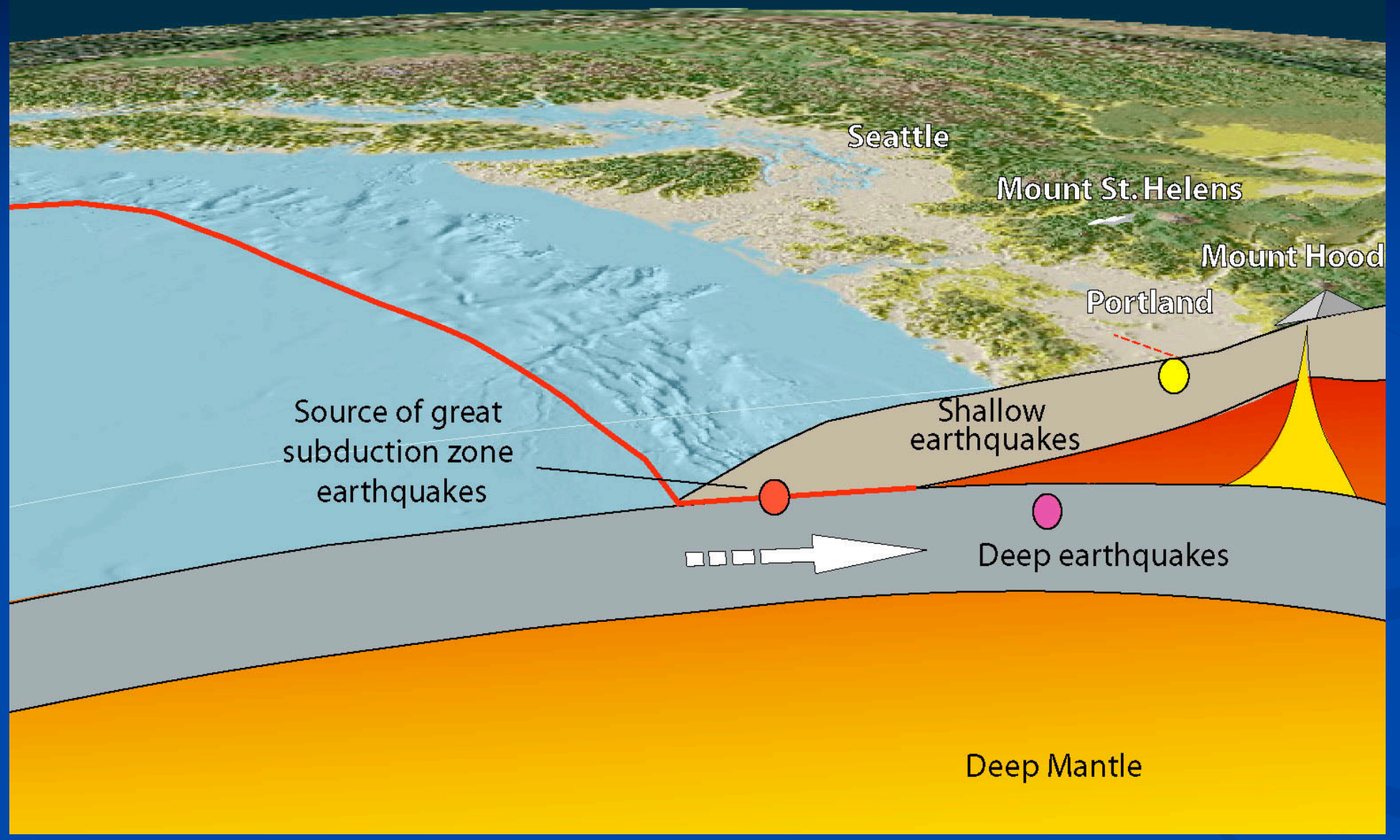

- This is where the Juan de Fuca oceanic plate dives beneath North America and sinks into the earth's deep mantle.

- This zone of convergence is called the Cascadia subduction zone, and it is the source of our rocks, geologic hazards, and landscape. 


\section{Outline of Talk}

- Rationale for USGS Geologic Mapping in Oregon

- Geologic map products

- Thumbnail sketch of geologic history

- New mapping in progress - NW Oregon

- Tour of NW Oregon geologic units

- Online sources of information 


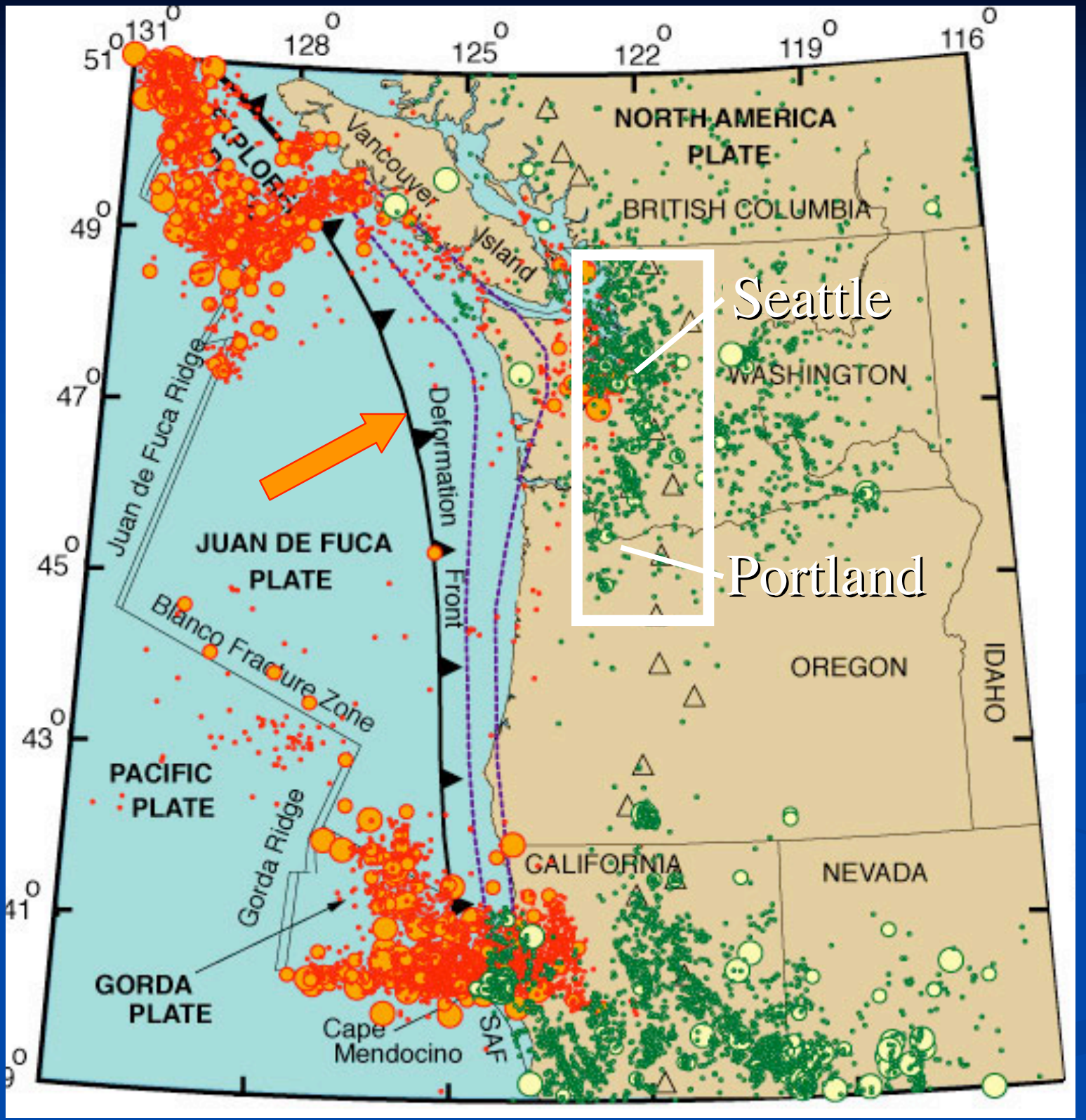

ᄂ

\section{Subduction}

creates

earthquakes and volcanoes

Urban Corridor is seismically active and is an area of intense study by USGS.

Earthquakes:

Green $=$ N. Am plate Red $=$ J. de Fuca plate Triangles=major volcanoes 


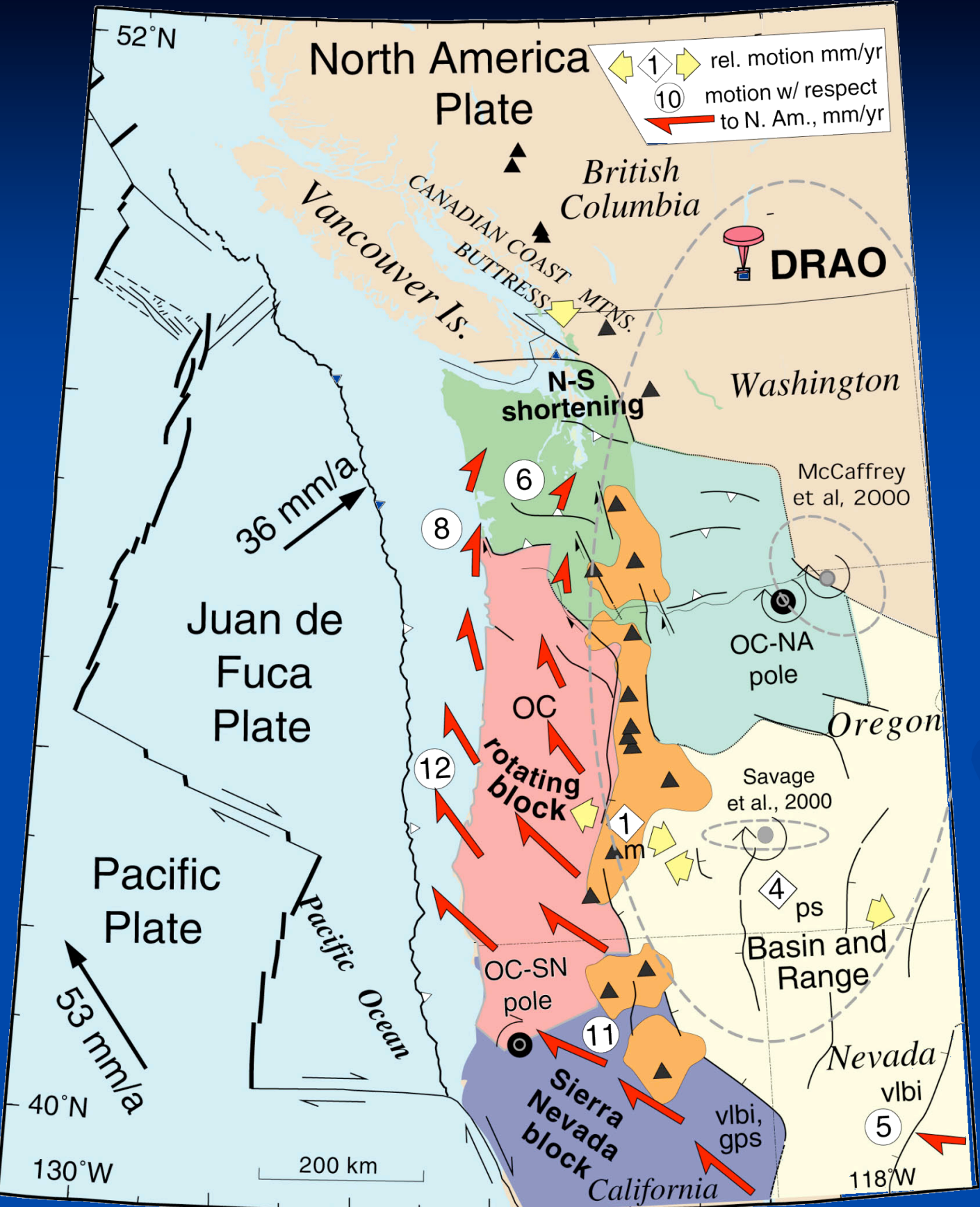

\section{Earthquakes}

are created by motions of crustal blocks

- Small plates and blocks are dragged northward by Pacific Plate

- Blocks collide with one another - a terrane wreck - as they encounter the fixed buttress of Canada.

(from Wang et al., 2003, modified from Wells et al., 1998, Wells and Simpson, 2001; see also Magill et al., 1982; Walcott, 1993; Pezzopane and Weldon, 1993; Argus and Gordon, 1991) 


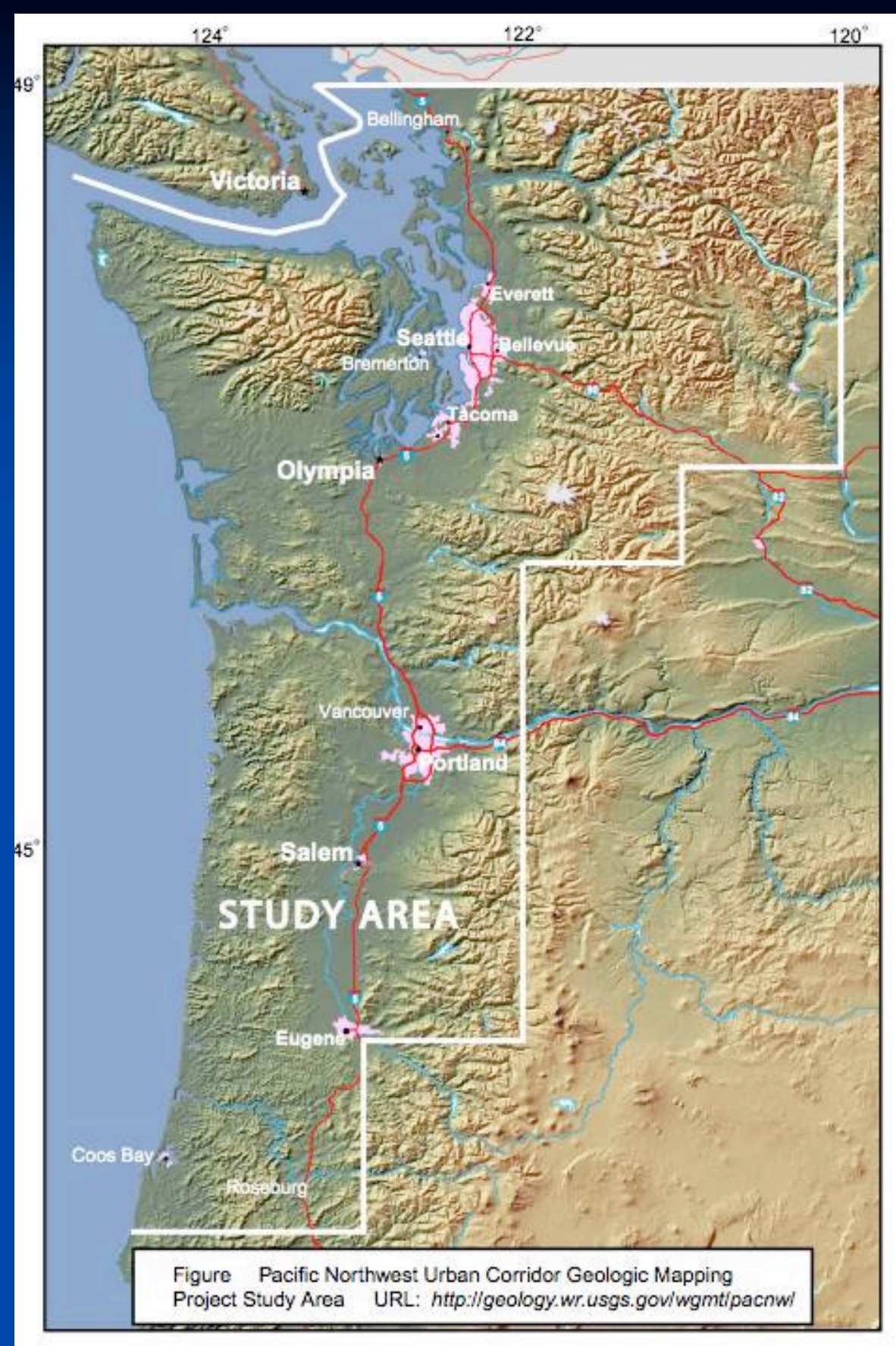

Geologic mapping is focused on convergent margin and I-5 Urban Corridor.

- Provide information useful for geologic hazard and resource assessments.

- Distribution, age, and composition of geologic units (rocks and sediments)

- Geometry and age of geologic structure (folds and faults) 


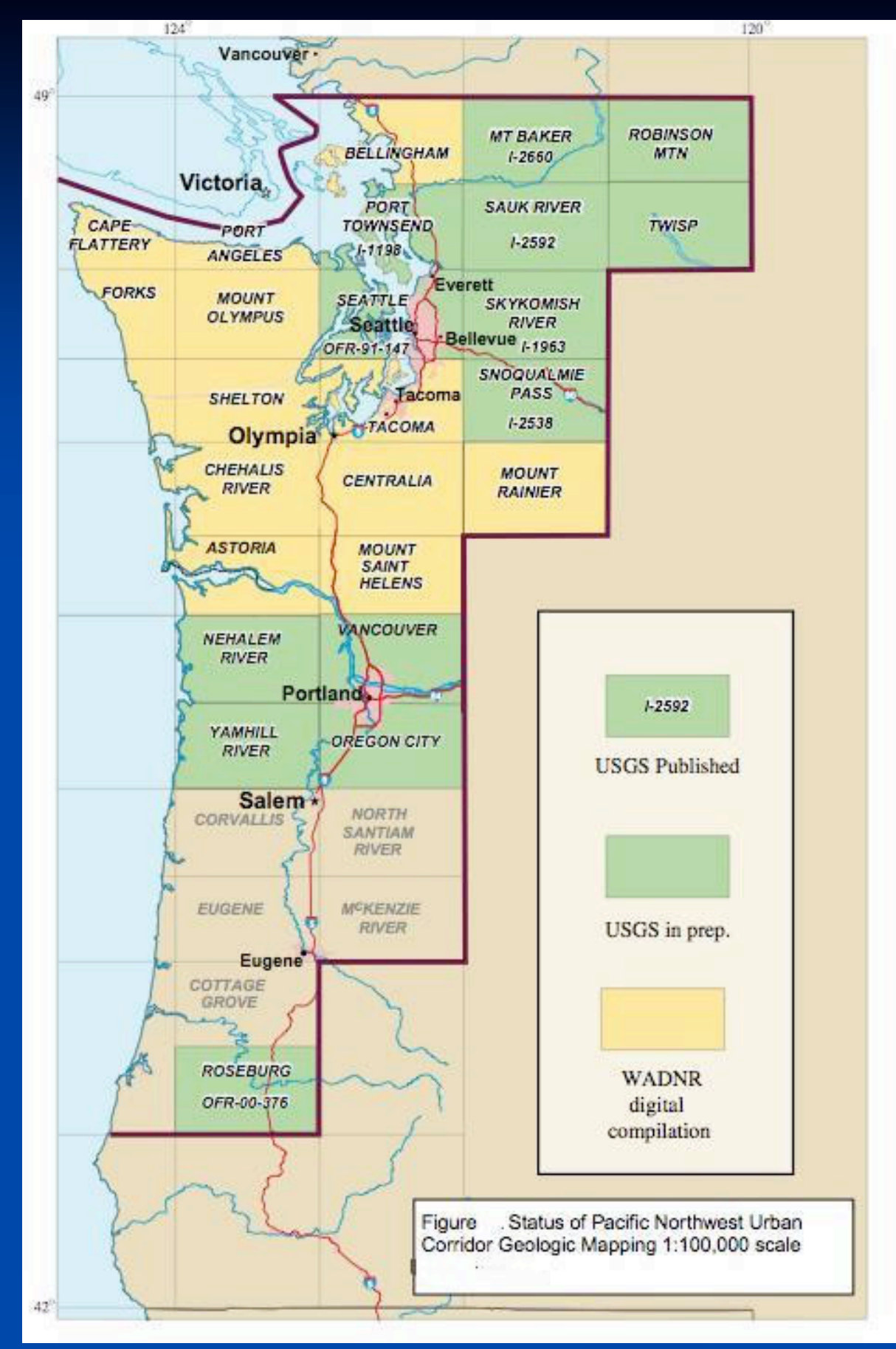

\section{K Geologic Mapping}

- Scale - 1:100,000 (1 inch on map $=1.6$ miles on ground)

- On the web as PDFs and ArcGIS files

- State of Washington has complete digital geologic coverage at this scale (WADNR)

- State of Oregon in progress 


\section{Geologic Map of Roseburg 100,000-scale quad}
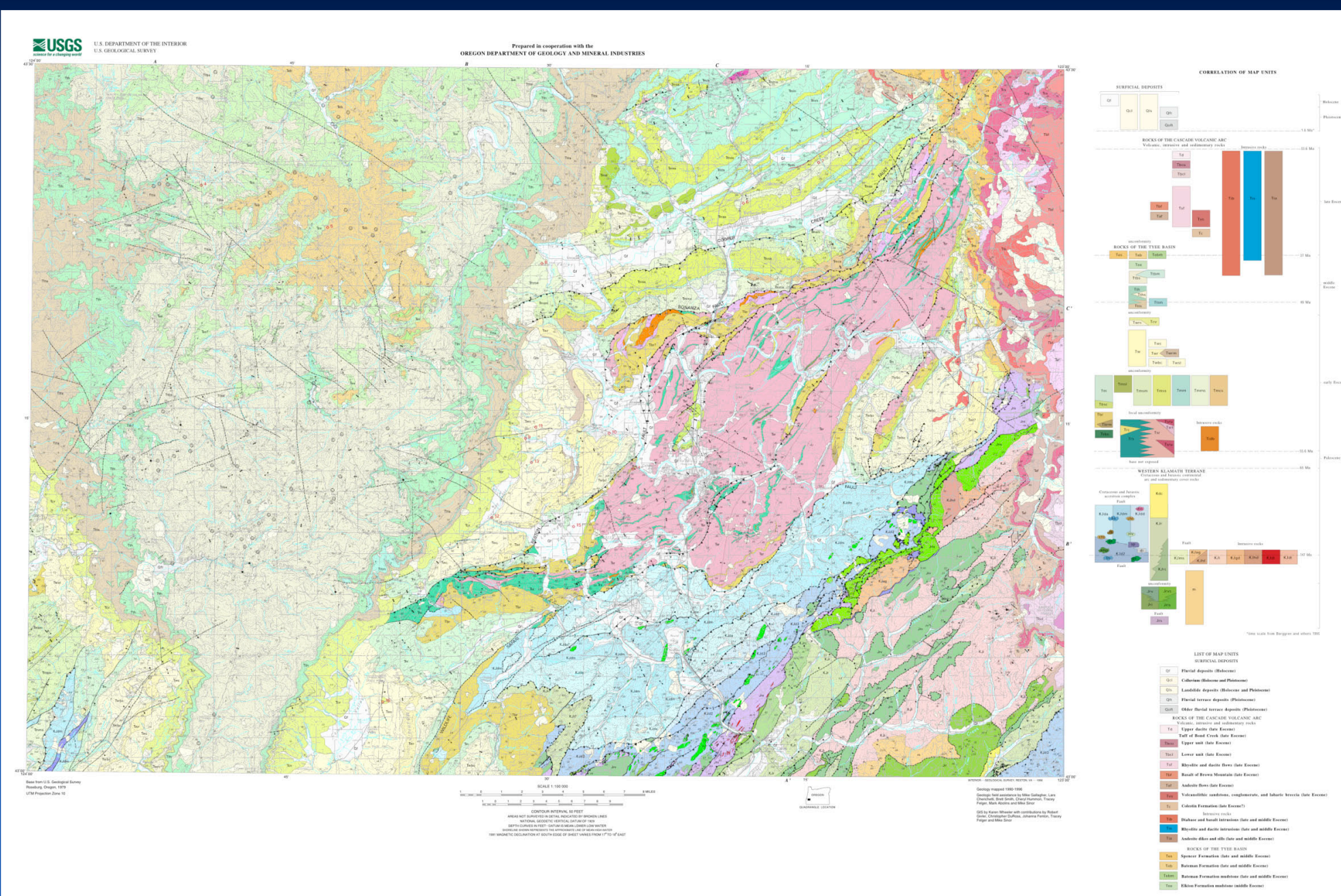

- Online at http://geopubs.wr.usgs.gov/open-file/of00-376/ 


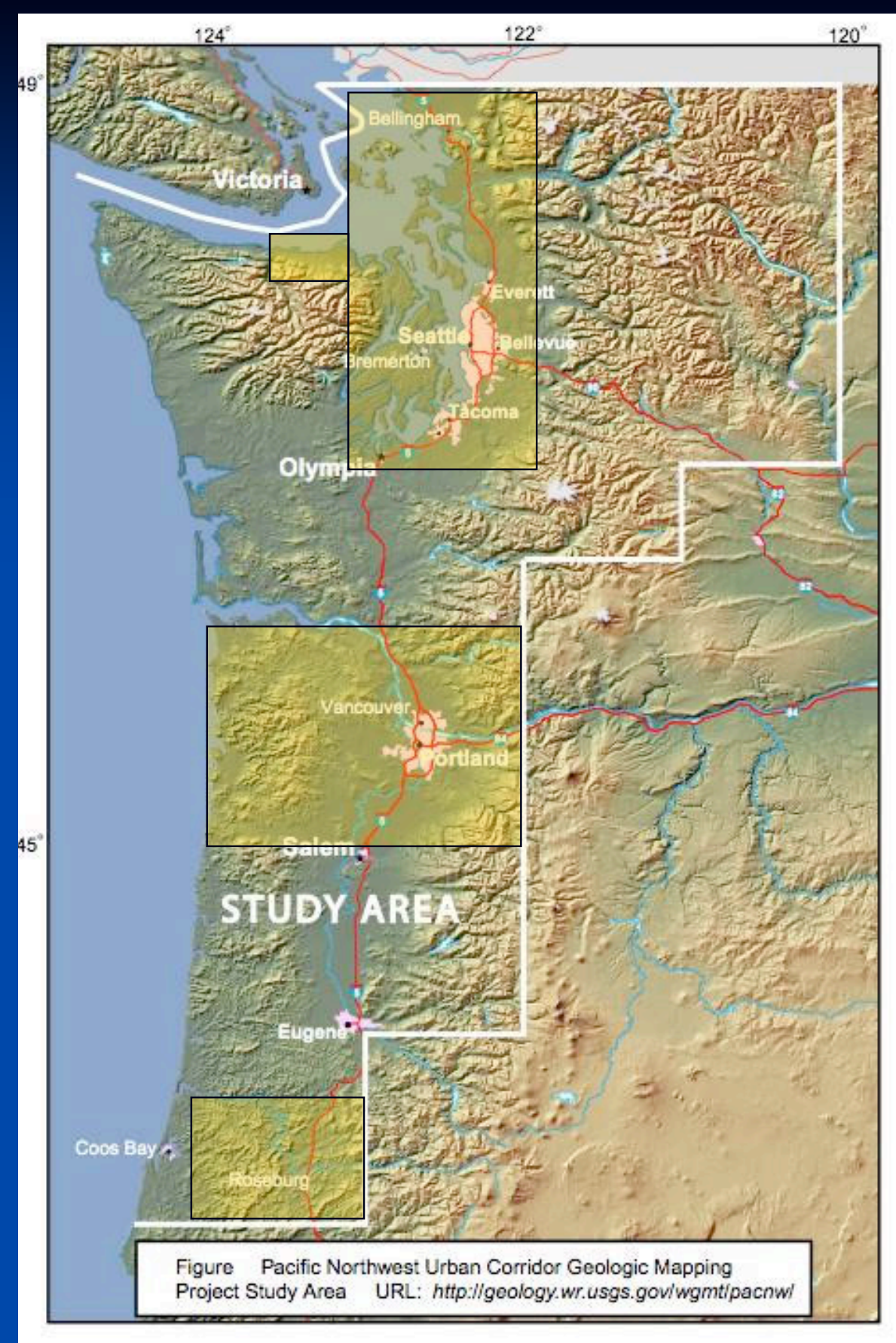

\section{5' quad geology}

- More detail - Scale is

1:24,000 (1 inch on map

$=0.38$ miles on ground)

- I-5 Urban Corridor

- On line as PDFs and ArcGIS geodatabases

- OR and WA state surveys (DOGAMI and WADNR) also publish similar maps 


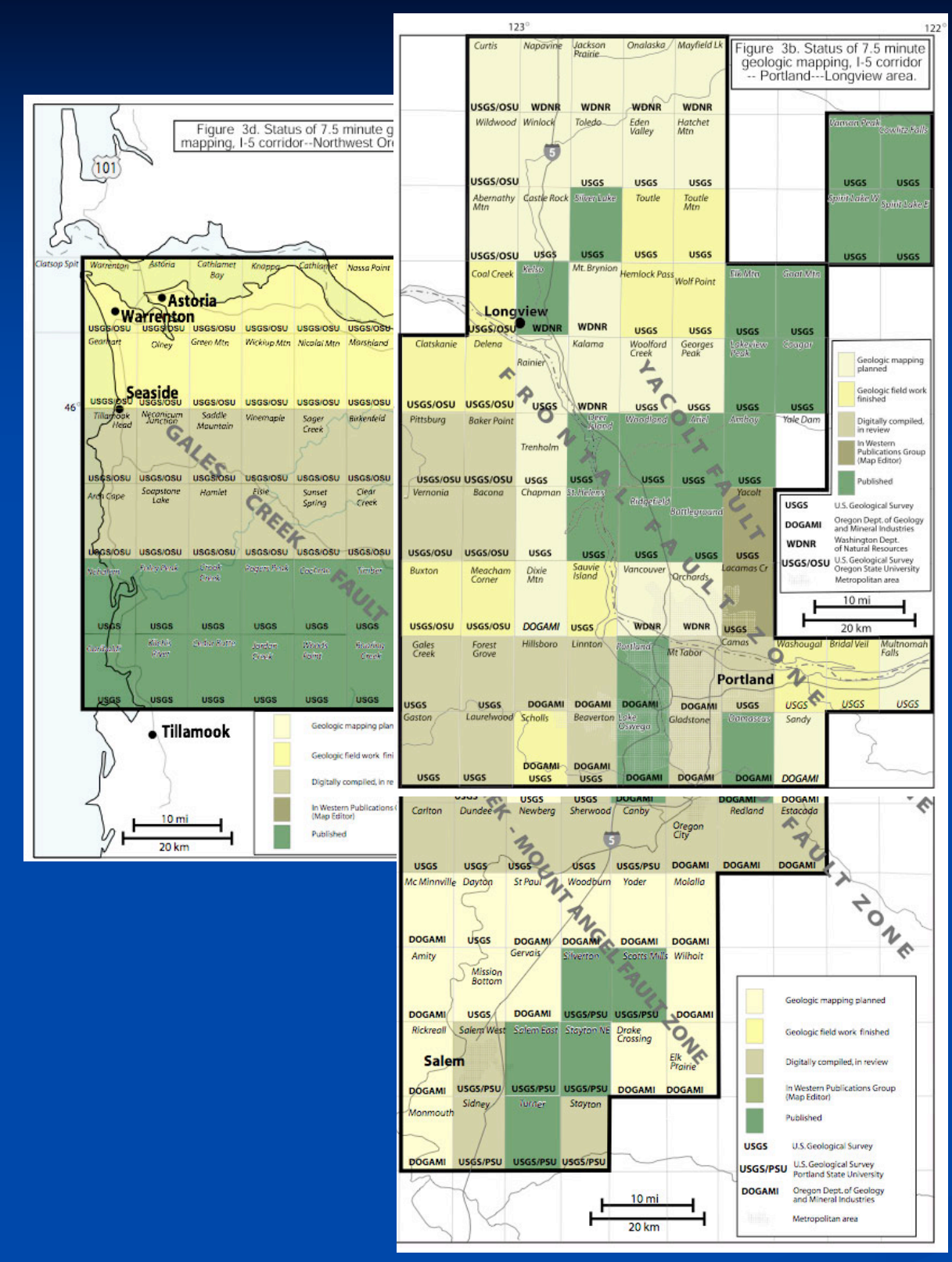

\section{mapping Portland- Salem area}

- $1397.5^{\circ}$ quads published or in progress by USGS, DOGAMI, WADGER, OSU, and PSU along I-5 corridor and major fault zones

- All will be digital and available online 


\section{Online 7.5' map Deer island, OR-WA}

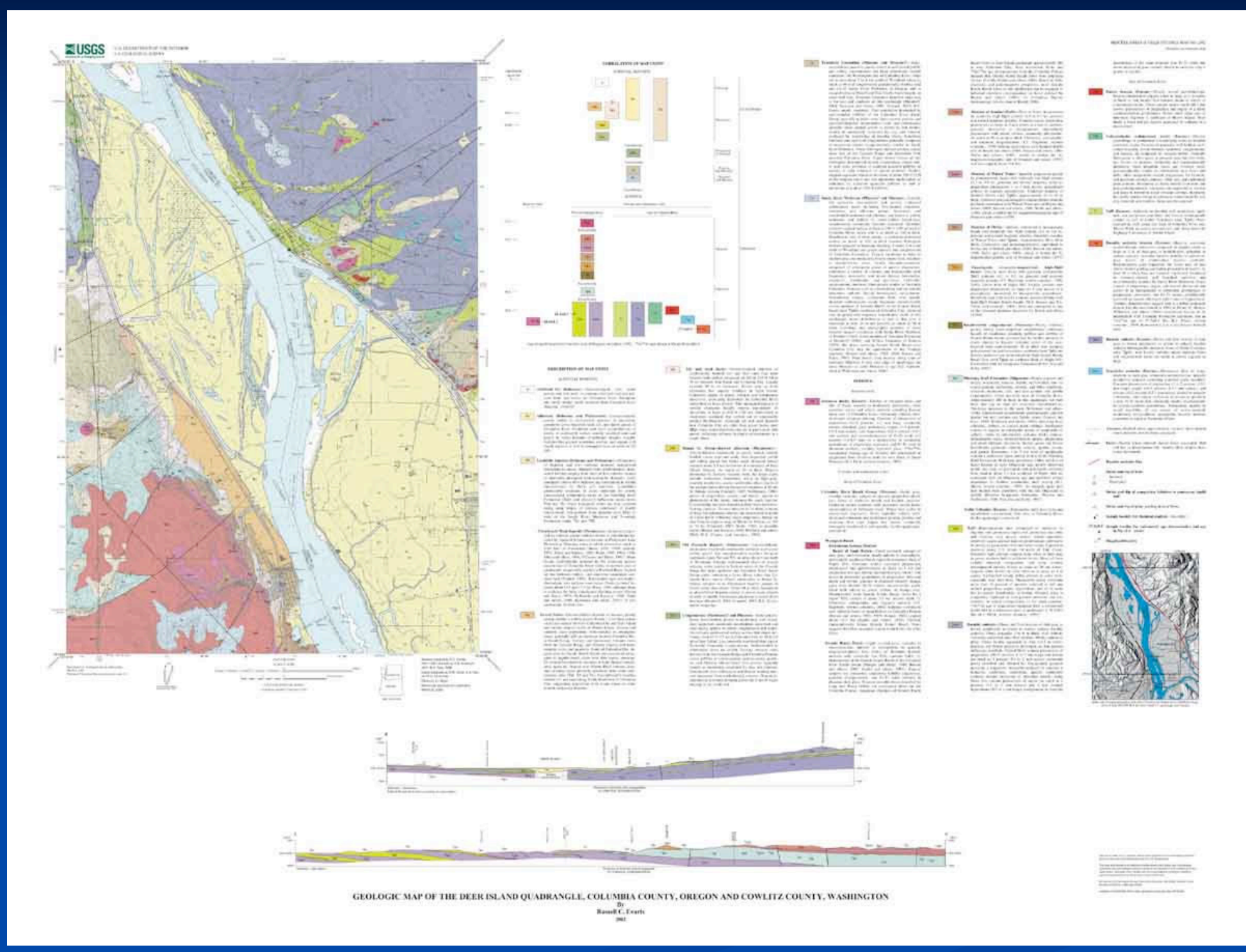

Evarts and others, 2002; http://pubs.usgs.gov/mf/2002/2392/ 


\section{Distribution of geologic maps online:}

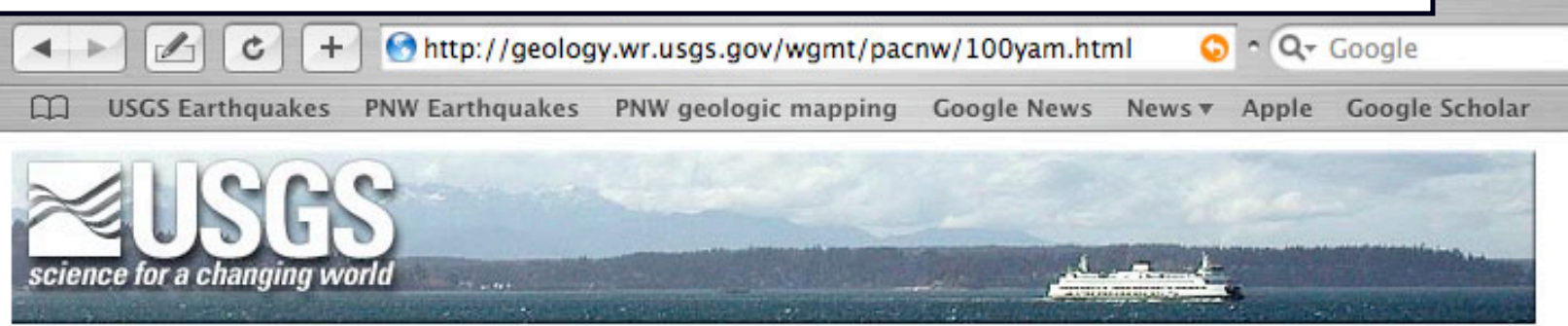

Pacific Northwest geologic mapping and urban hazards

Home What's new Find maps Current research Publications Links \& resources site m http://geology.wr.uSgS.gov/

You are here: $\underline{\text { Home }}>$ Find maps $>$ Pacific Northwest Project geologic maps $>$ Yamhill River, OR 30' $\times 60^{\circ}$

wgmt/pacnw

Find geologic

maps

Yamhill River, OR

7.5' maps

Amity

Ballston

Beaver

Blaine

Carlton

Dayton

Dolph

Dovre Peak

Dundee

Fairdale

Gaston

Gobblers Knob

Grand Ronde

Hebo

Laurelwood

Mcminnville

Midway

Mission Bottom

Muddy Valley

Neskowin

Nestucca Bay
Pacific Northwest Urban Corridor Geologic Maps

Geologic maps and databases of the Yamhill River, OR 30' x 60' Quadrangle
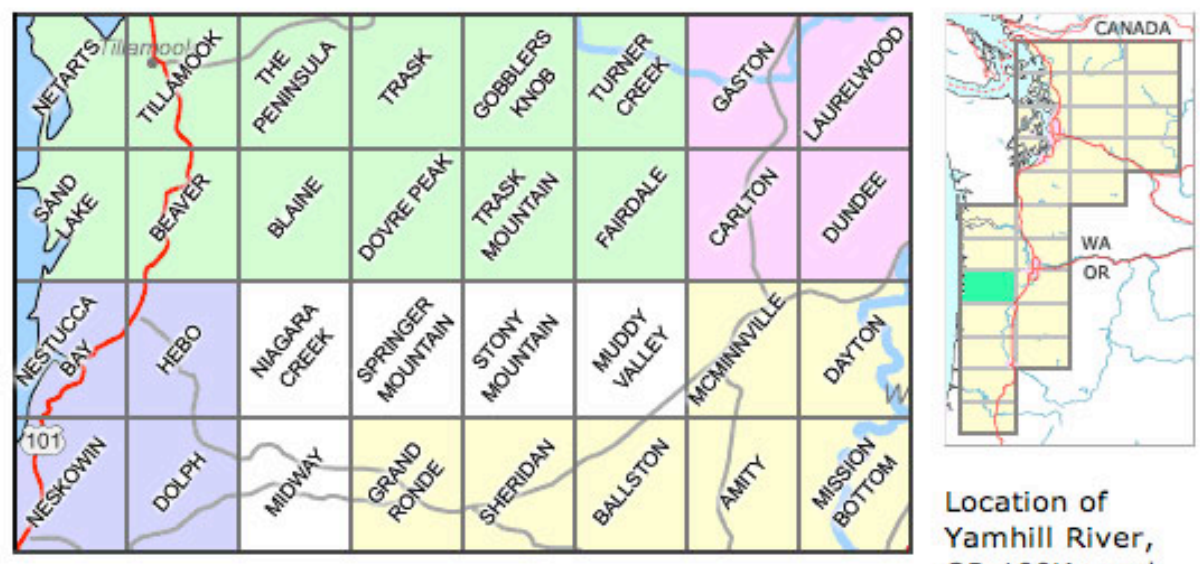

Location of

Yamhill River, OR $100 \mathrm{~K}$ quad.

Index to 7.5' geologic quadrangle maps. Green links to

online USGS maps; purple links to USGS paper maps; pink

links to USGS maps in preparation; yellow links to Oregon

Dept. of Geology and Mineral Industries maps. 


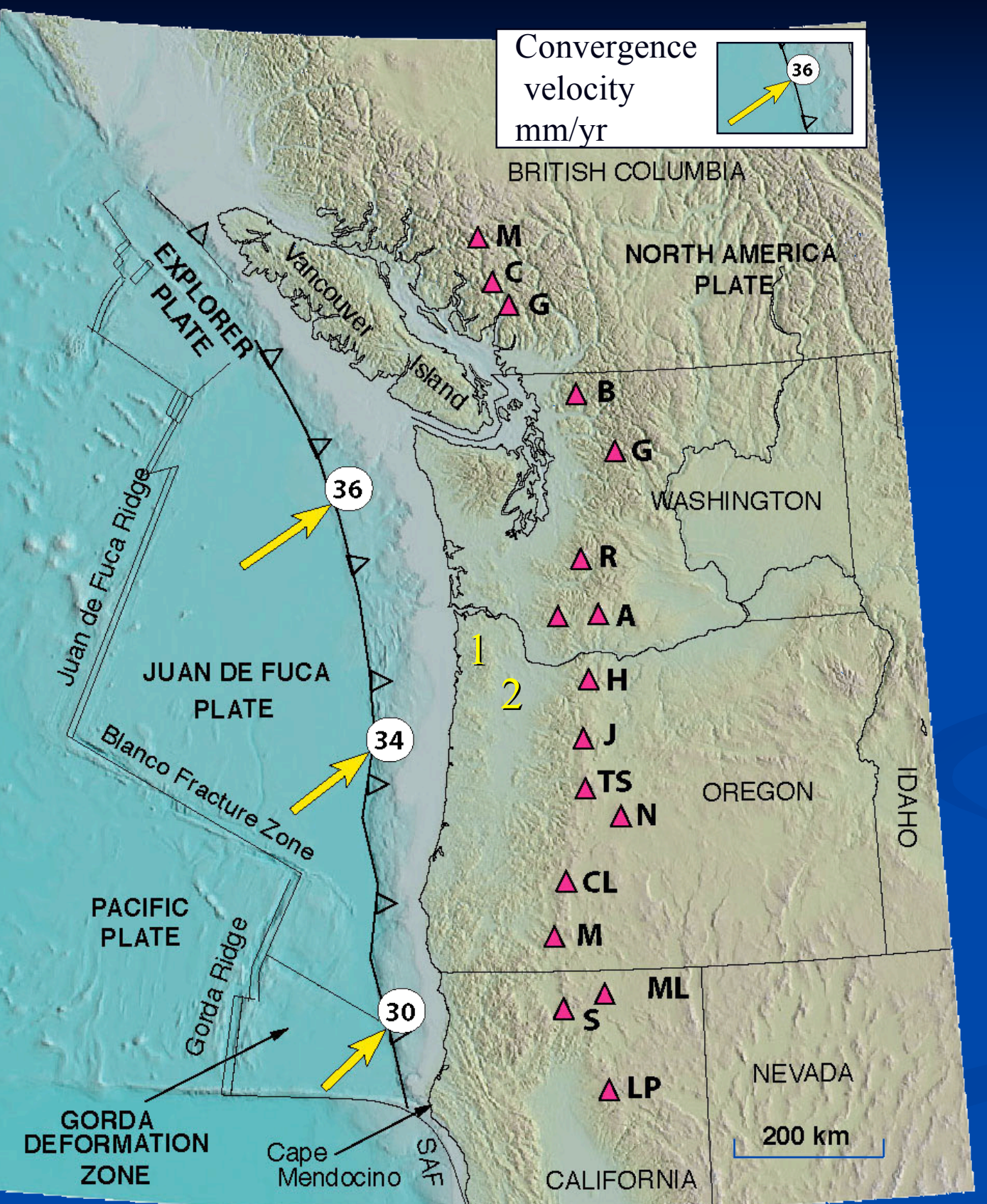

\section{Cascadia Physiography}

Subduction of Juan de Fuca plate:

- Holds up Coast Range (1)

- Depresses PugetWillamette trough (2)

- Builds active Cascade volcanic arc (triangles) 


\section{Cascadia's geologic history - A thumbnail sketch of 6 big events:}

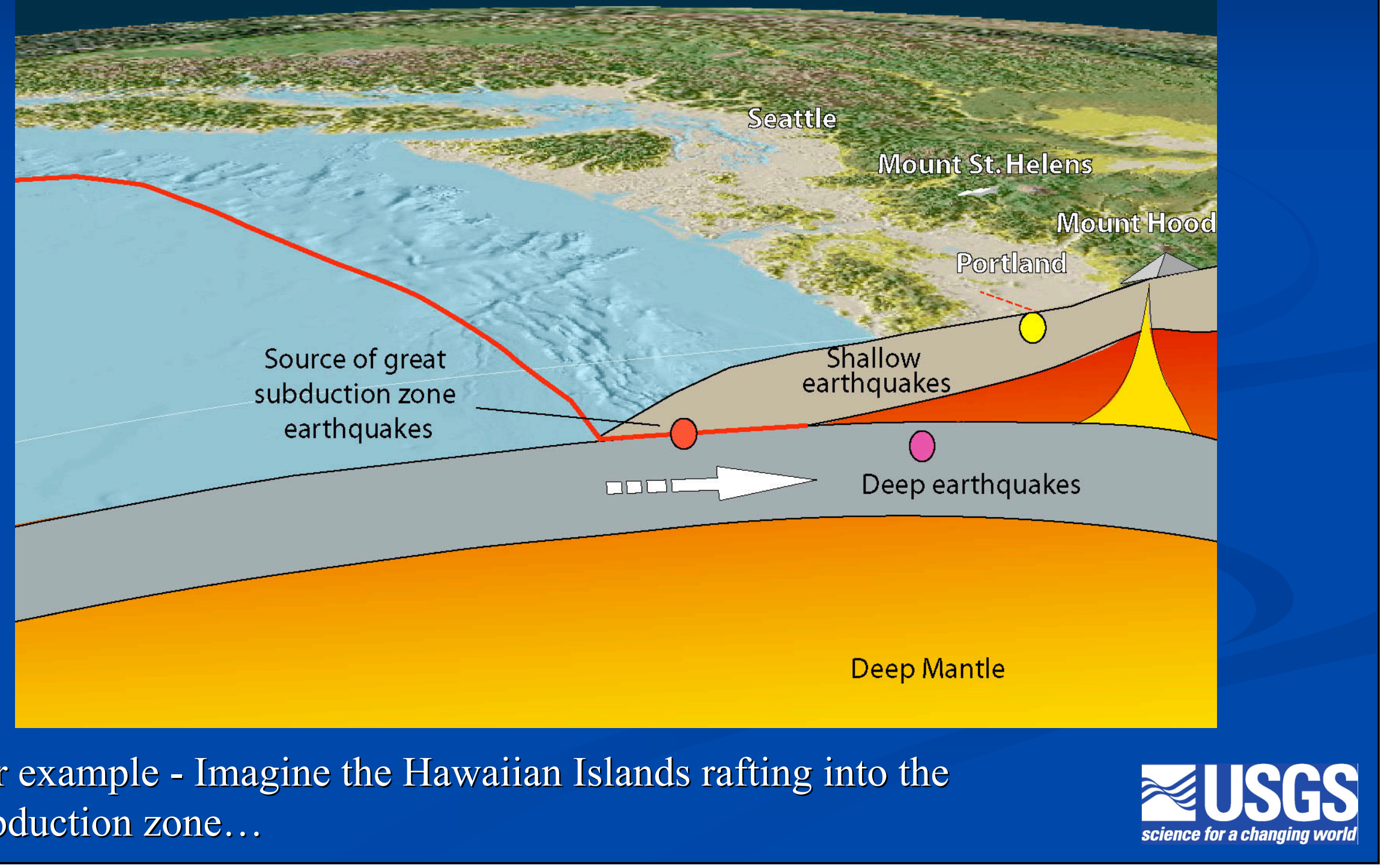




\section{Collision of ocean island chain with}

\section{continent}

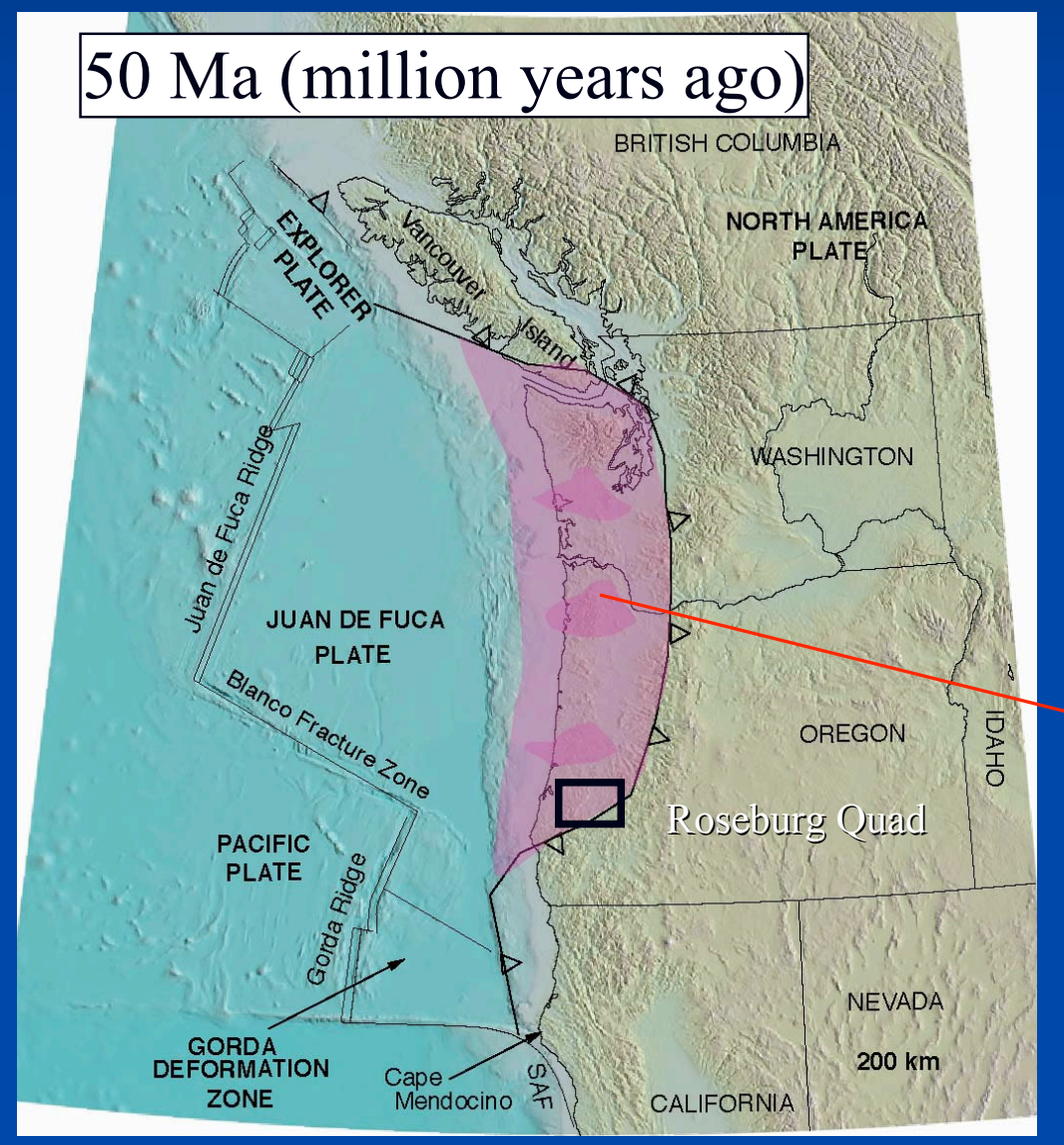

52 million-year-old submarine pillow basalt, Trask River
- Island chain - similar to Hawaiian Islands - crashed into N. America and was accreted to the continent at about $50 \mathrm{Ma}$ (million years ago).

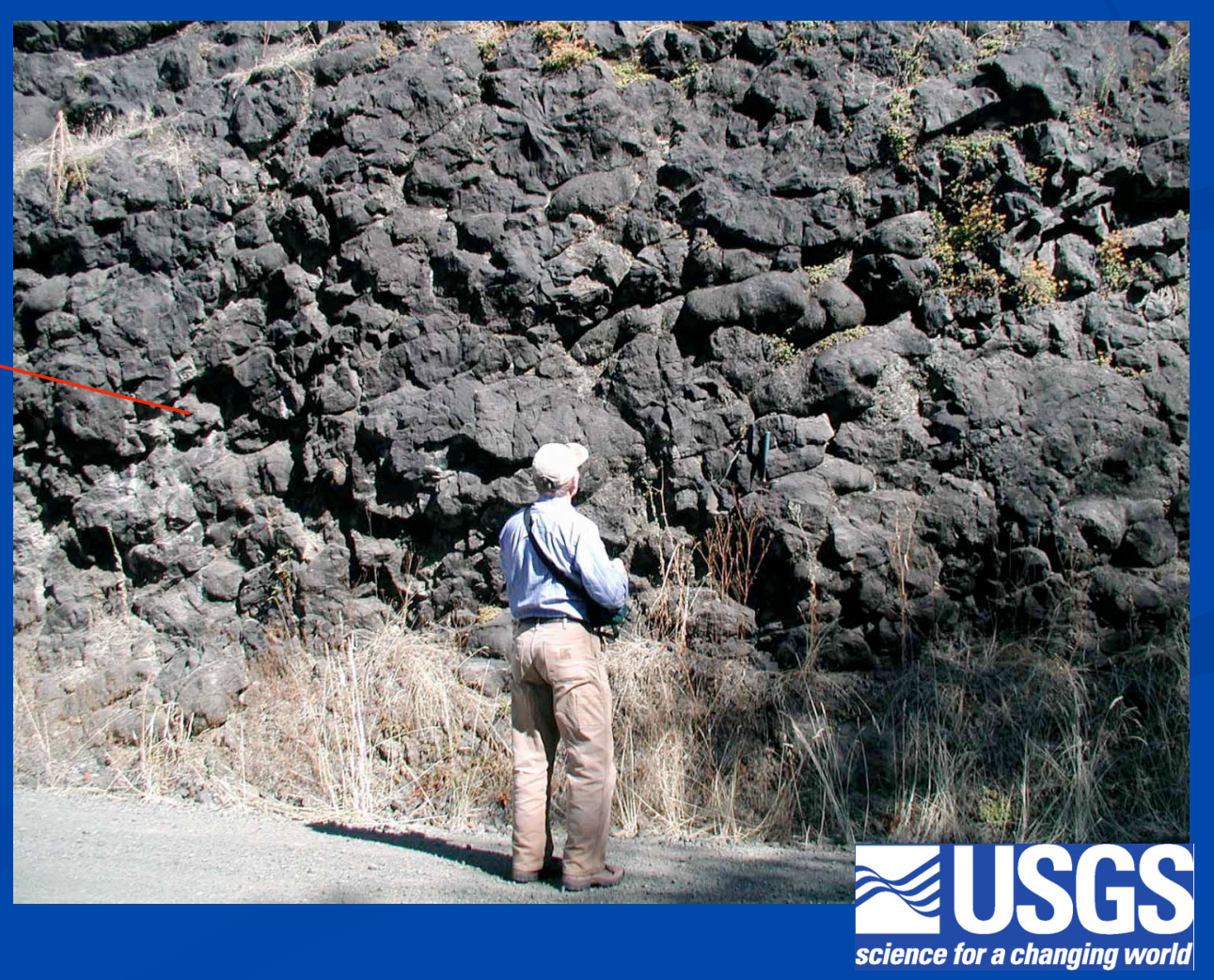




\section{Marine sediments were deposited on the}

accreted terrane in W. Oregon and Washington

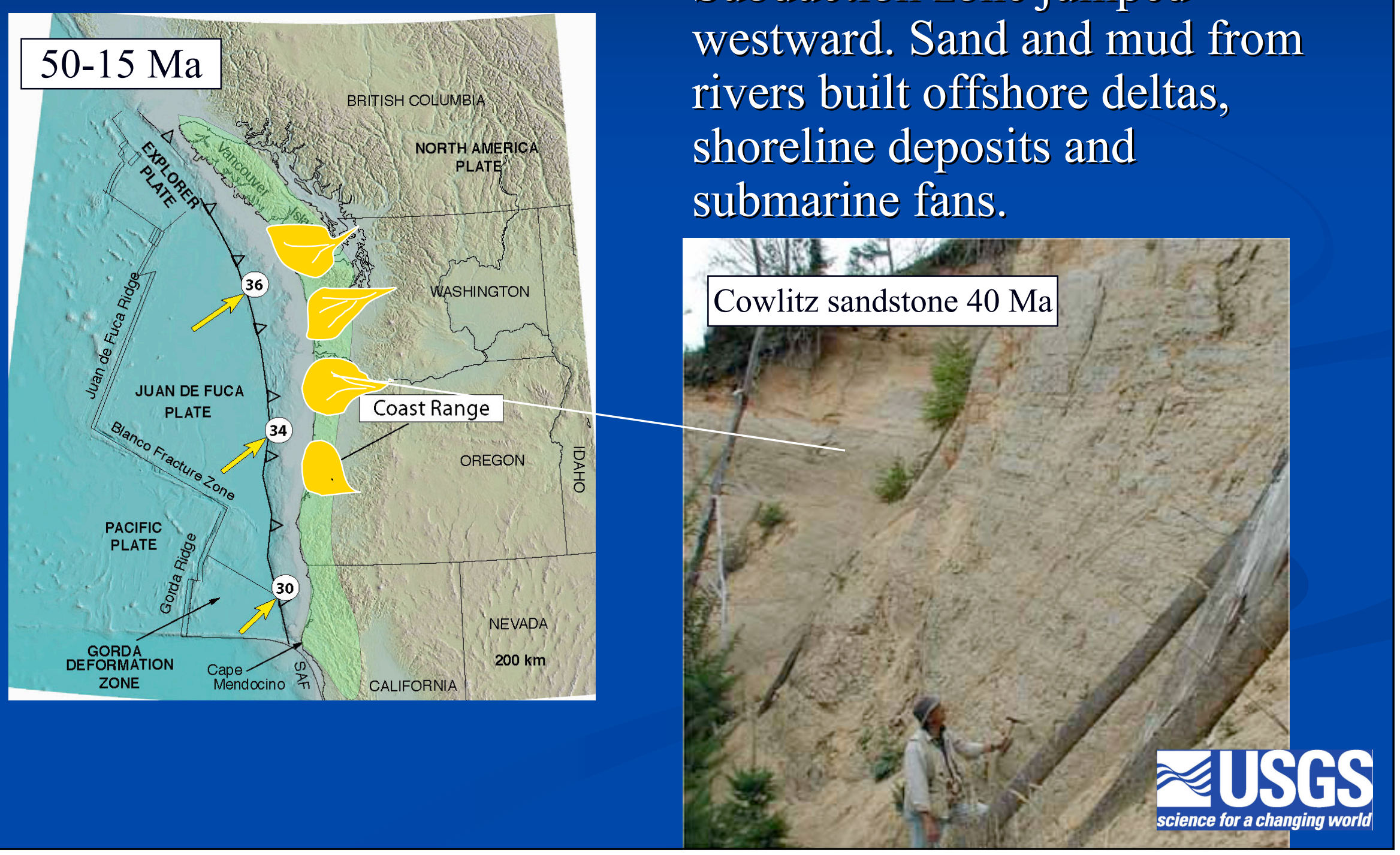




\section{Cascade arc volcanoes buried the eastern edge of the marine sediments and the}

\section{accreted terrane.}

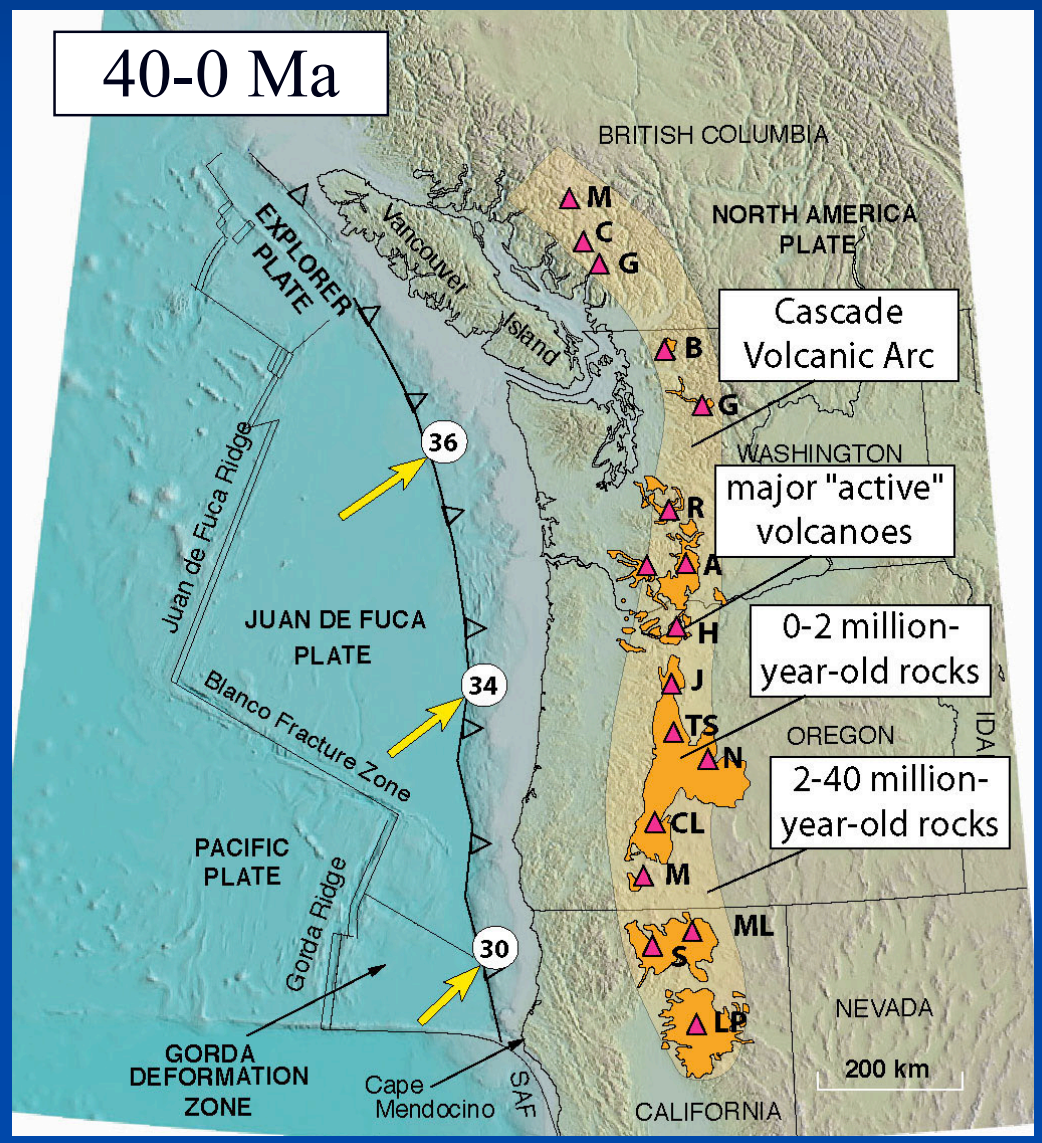

- Volcanic activity continues to the present.

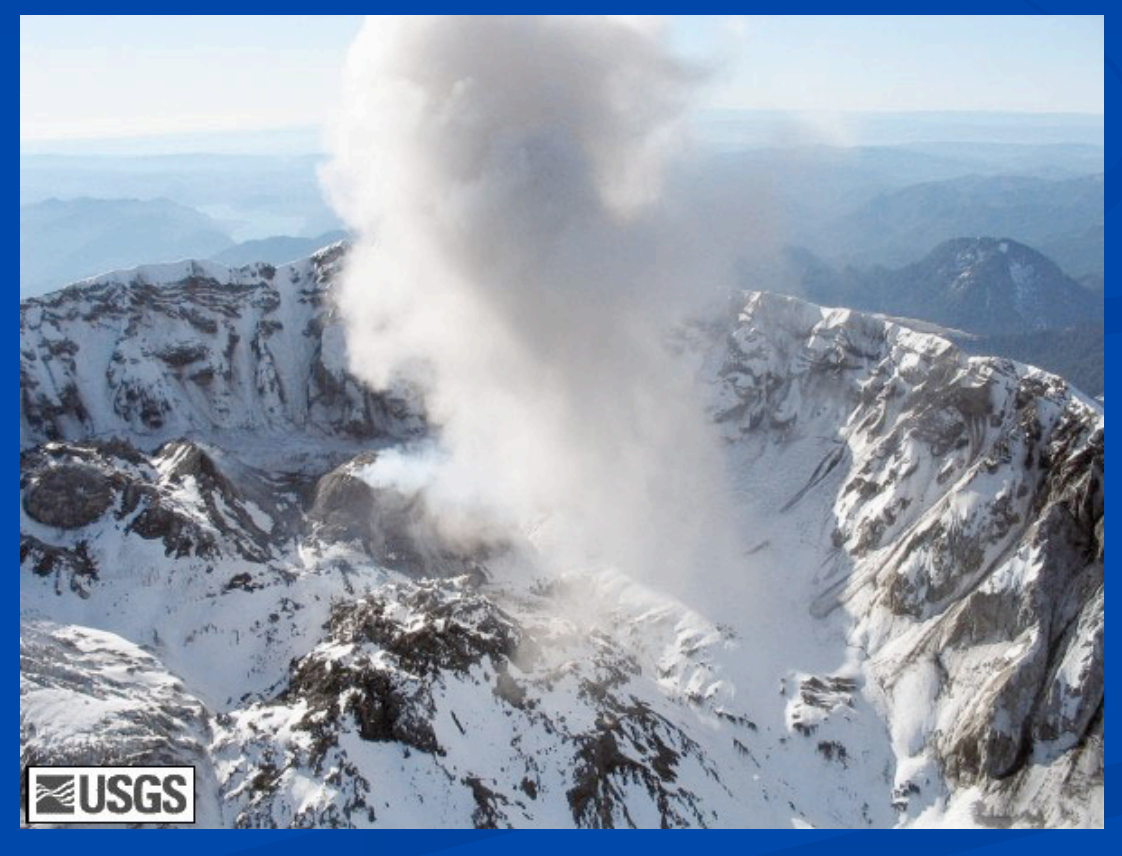

Mount St. Helens Nov 05 


\section{Crustal stretching released a flood of basalt from fissures east of the arc}

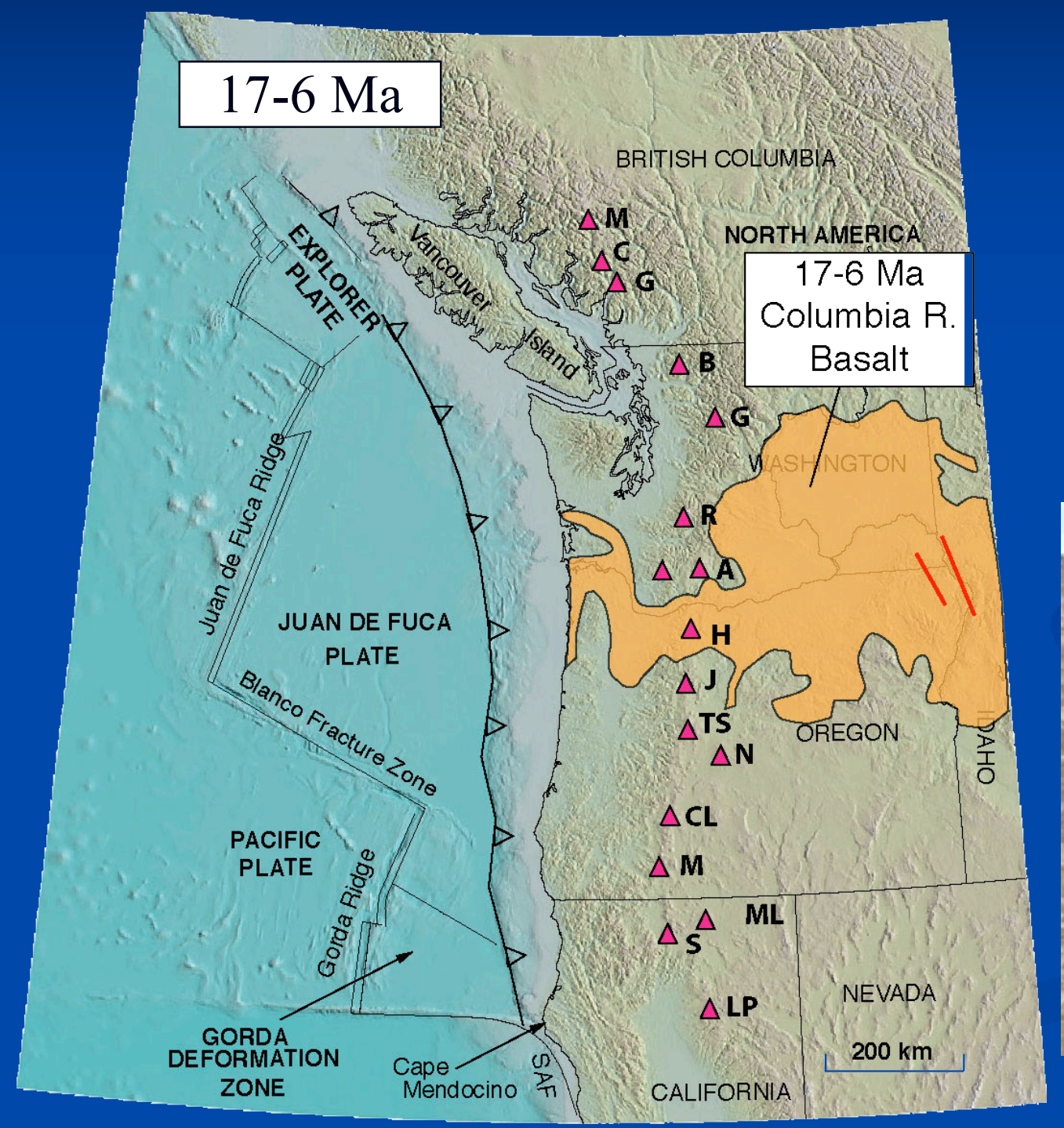

- Columbia River Basalt (CRB)

- $80 \%$ by volume erupted between 16.2 and $15.5 \mathrm{Ma}$

- Flowed 450 mi. into Pacific Ocean

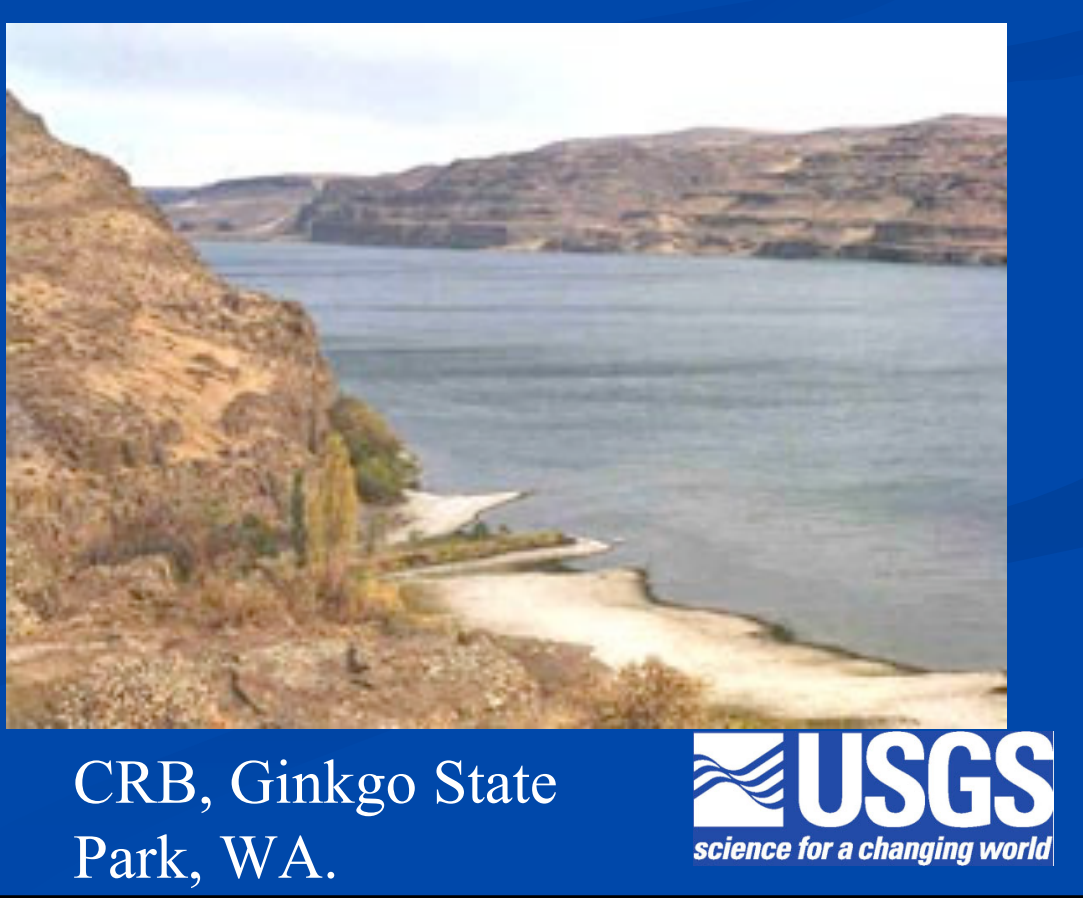




\section{The resulting rock sequence in NW Oregon:}

\section{History}

- Modern rivers

- Glacial outburst floods (Missoula flood)

- Columbia R. Basalt

- Deposition of shallow-water marine sediments

- Deposition of deep marine sediments basalt intrusion

- Accretion of oceanic basalt terrane to N. America "Siletzia"

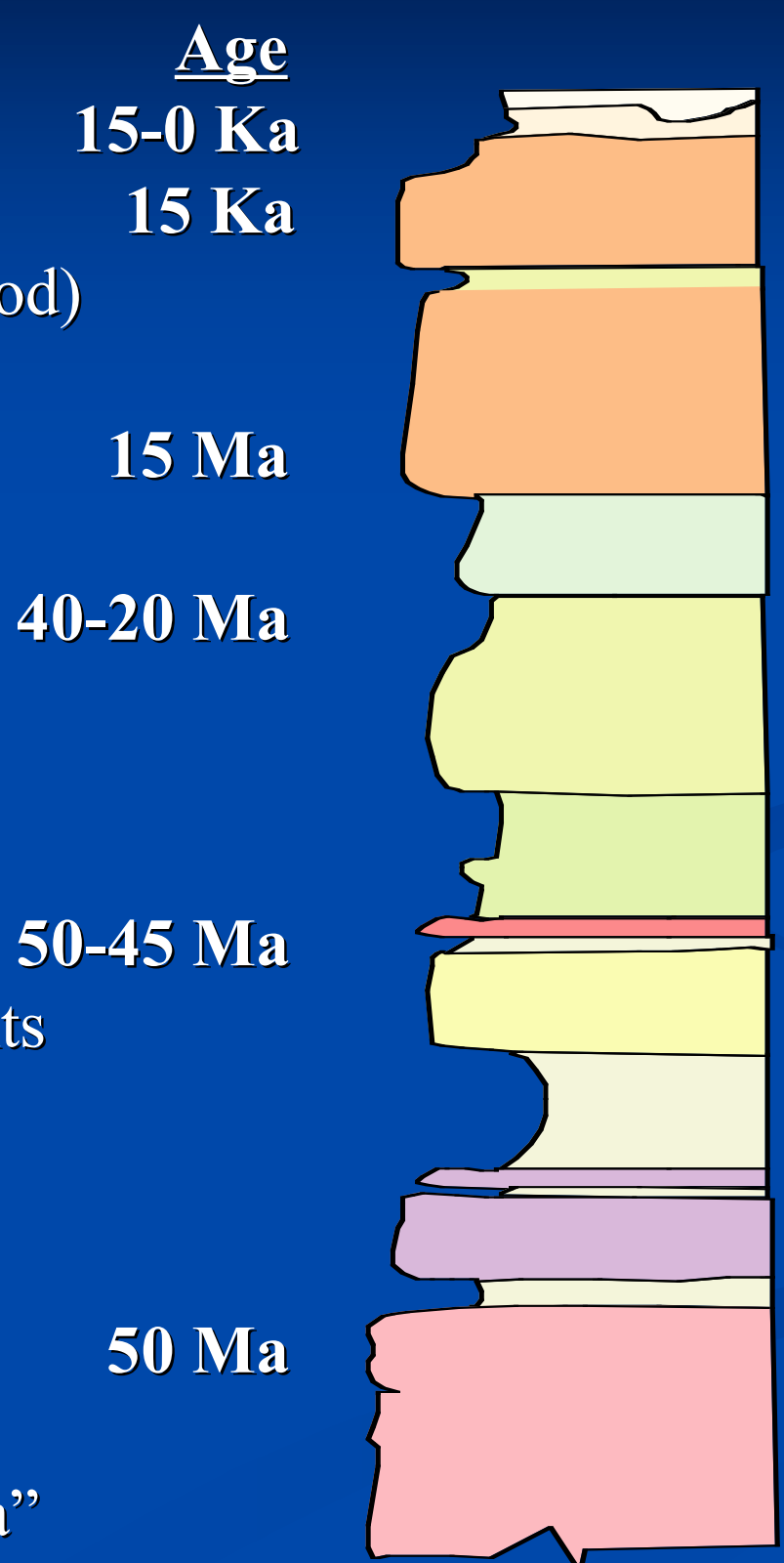

Rock type

- Mud and sand

- Silt and sand

- Basalt lava flows

- Fine grained sandstone

- Sandstone

- siltstone

- Basalt intrusions

- Basalt flows (submarine pillow basalt) 


\section{5a. An eastward "push" from Juan de Fuca plate causes uplift of the Coast Range.}
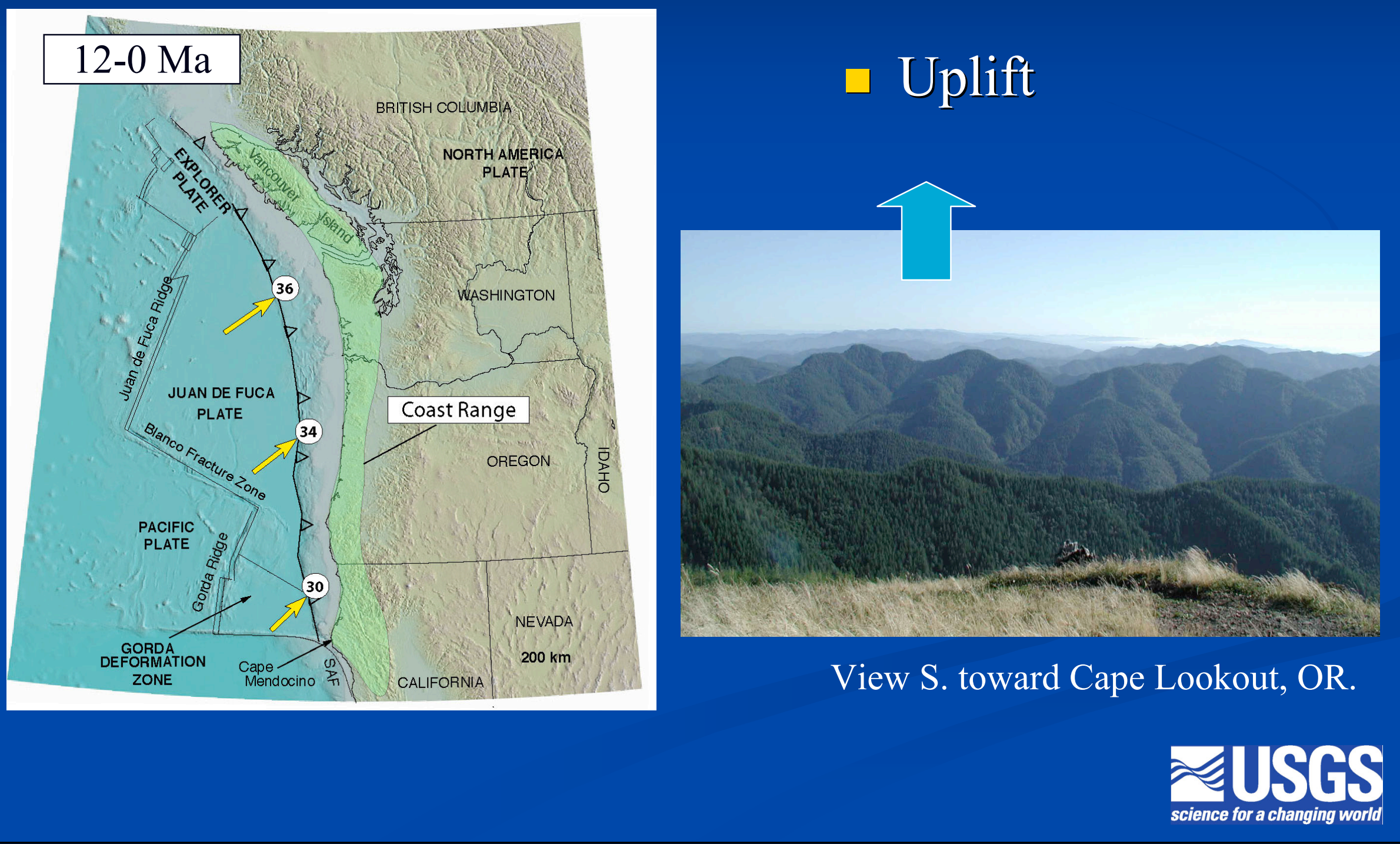


\section{5b. The strata in the uplifted Coast Range}

were folded into a broad arch, with the oldest rocks in the center.

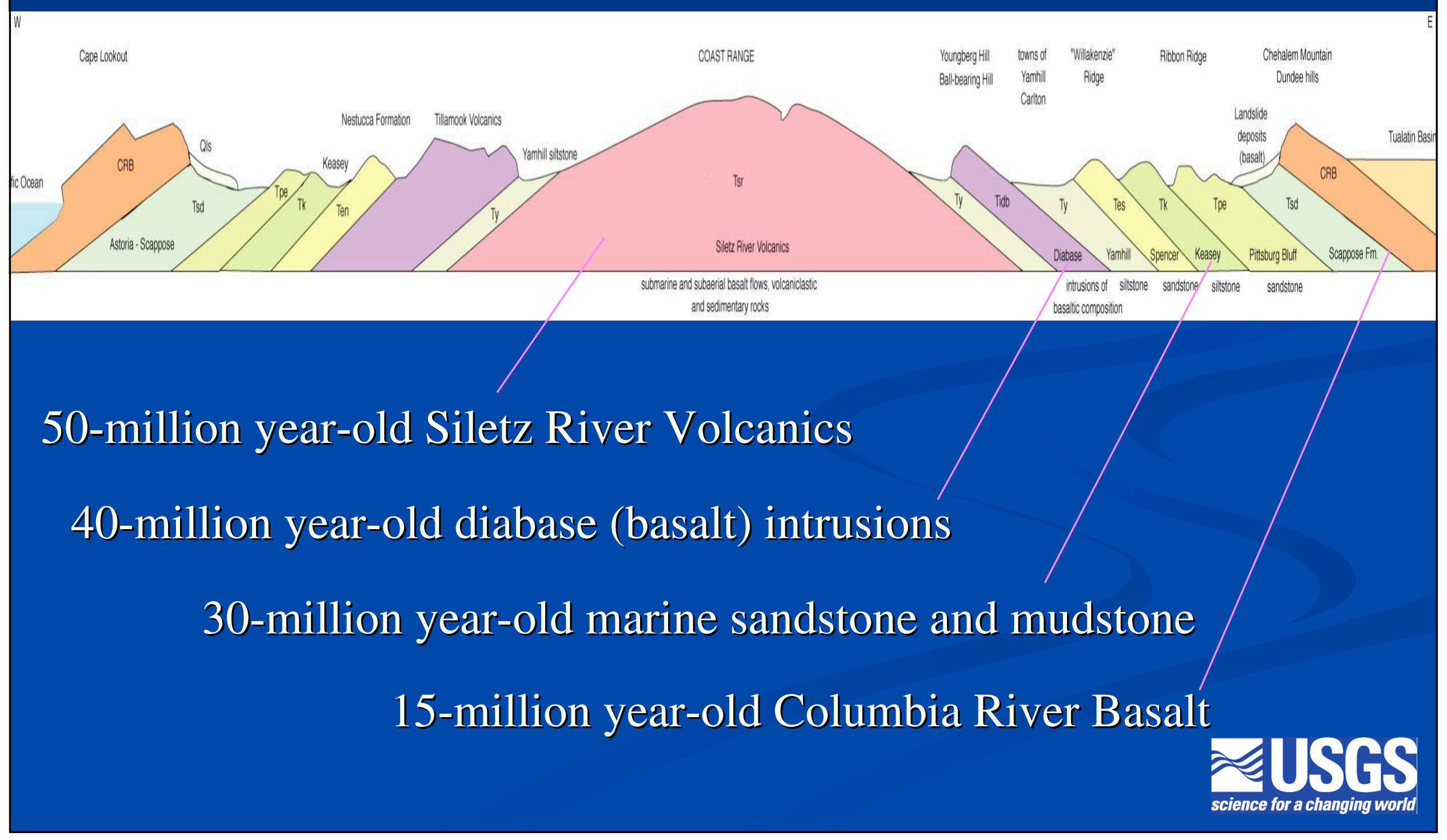




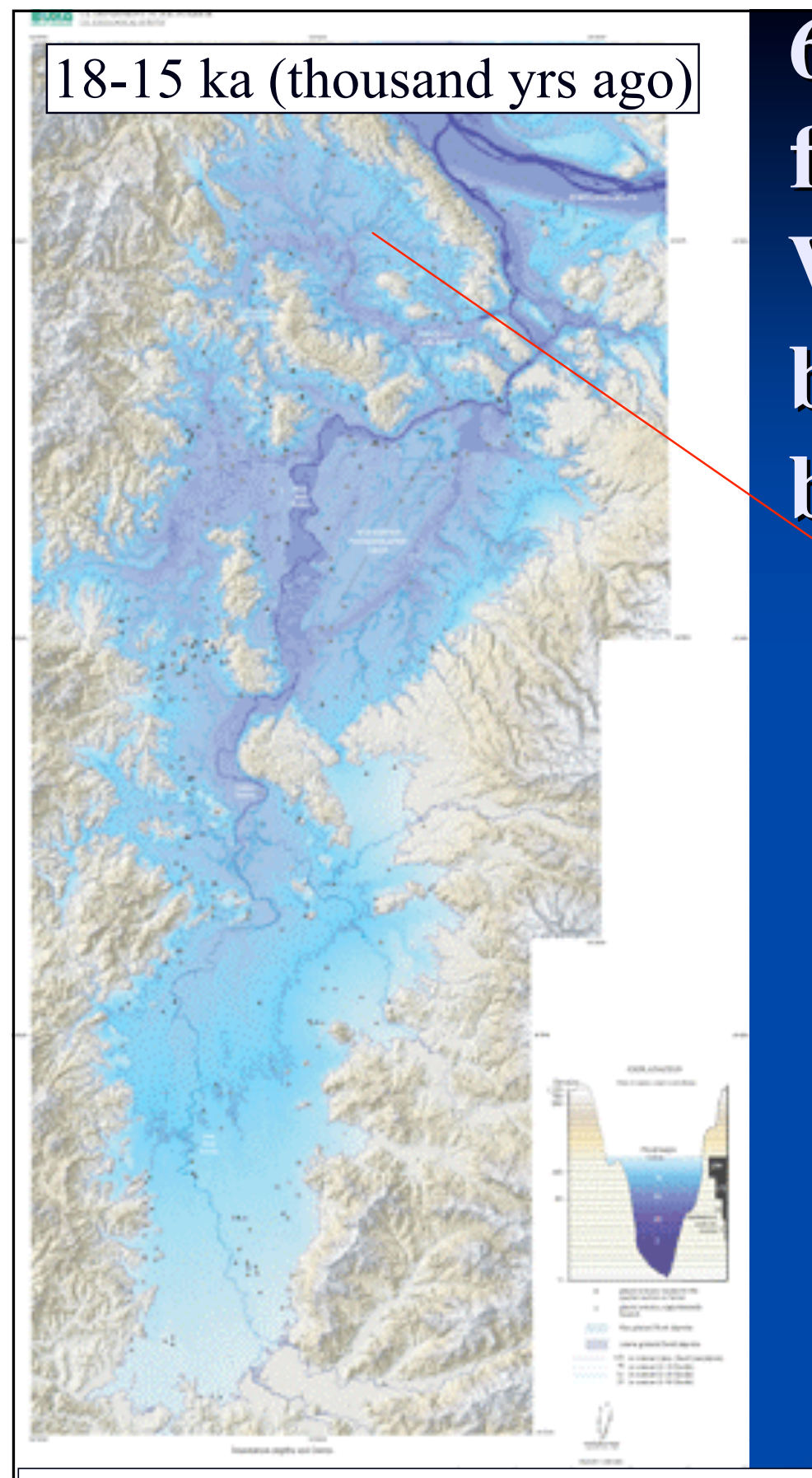

http://geopubs.wr.usgs.gov/open-file/of03-408/
6. Catastrophic glacial outburst floods (at least 40) filled the Willamette Basin, leaving a blanket of silt on everything below $\sim 400$ ' elevation.

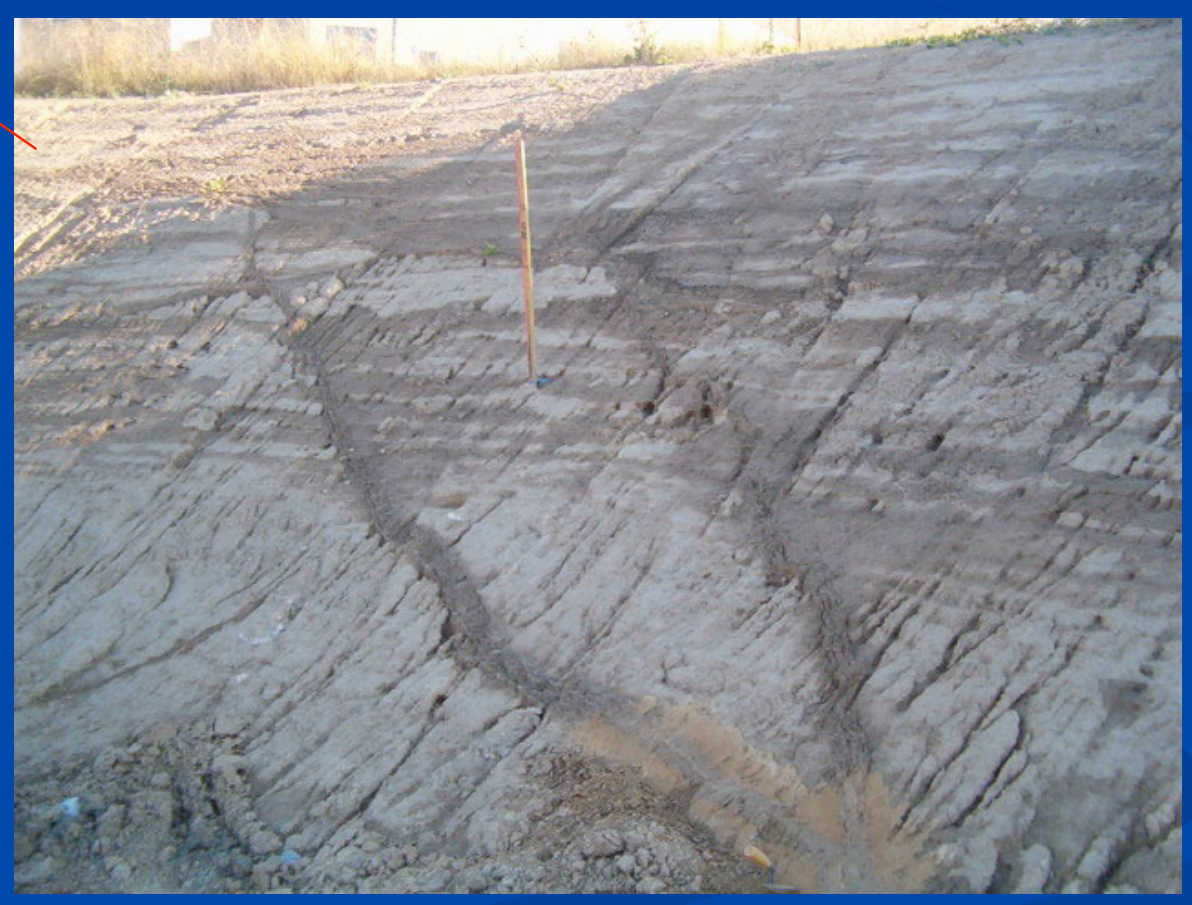

- 26 Rhythmically-bedded Missoula flood silts; Highway 26 at Cornell Rd. 


\section{Oregon Geologic Map}

- Areas of new USGS mapping in purple

- American Viticultural Areas (AVAs) in blue

- Area of detail in next slide

Qal alluvium

QLavas of Cascade Arc

CRB

Cascade1

Cascade2

CoastRange marine sedimentary rocks 2 CoastRange marine sedimentary rocks CoastRange oceanic island basalt pre-Tertiary
Geology simplified from Walker and Macleod, 1991

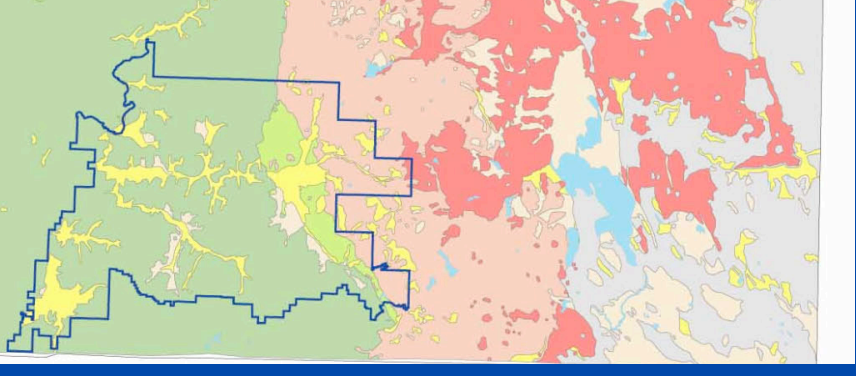




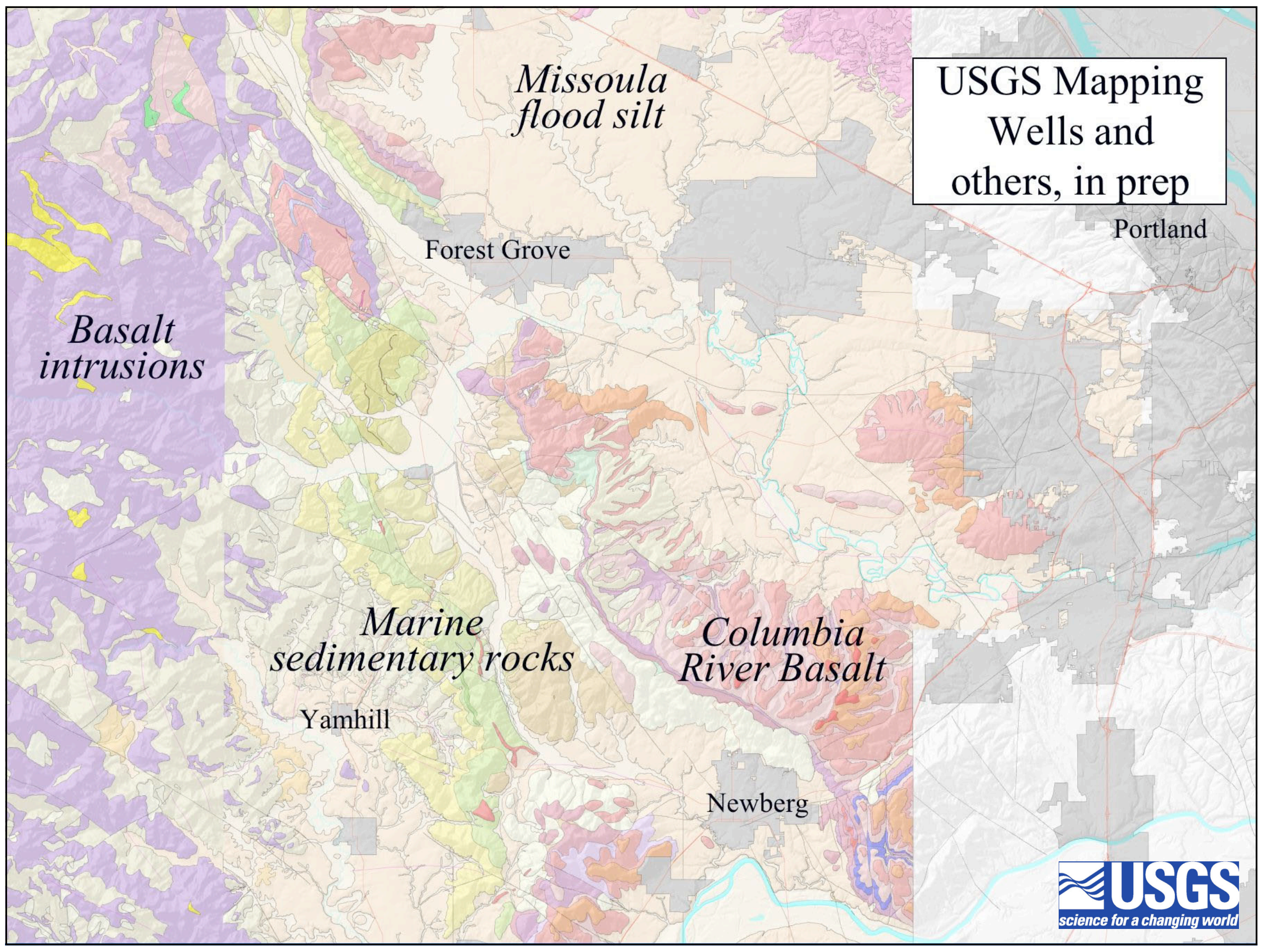




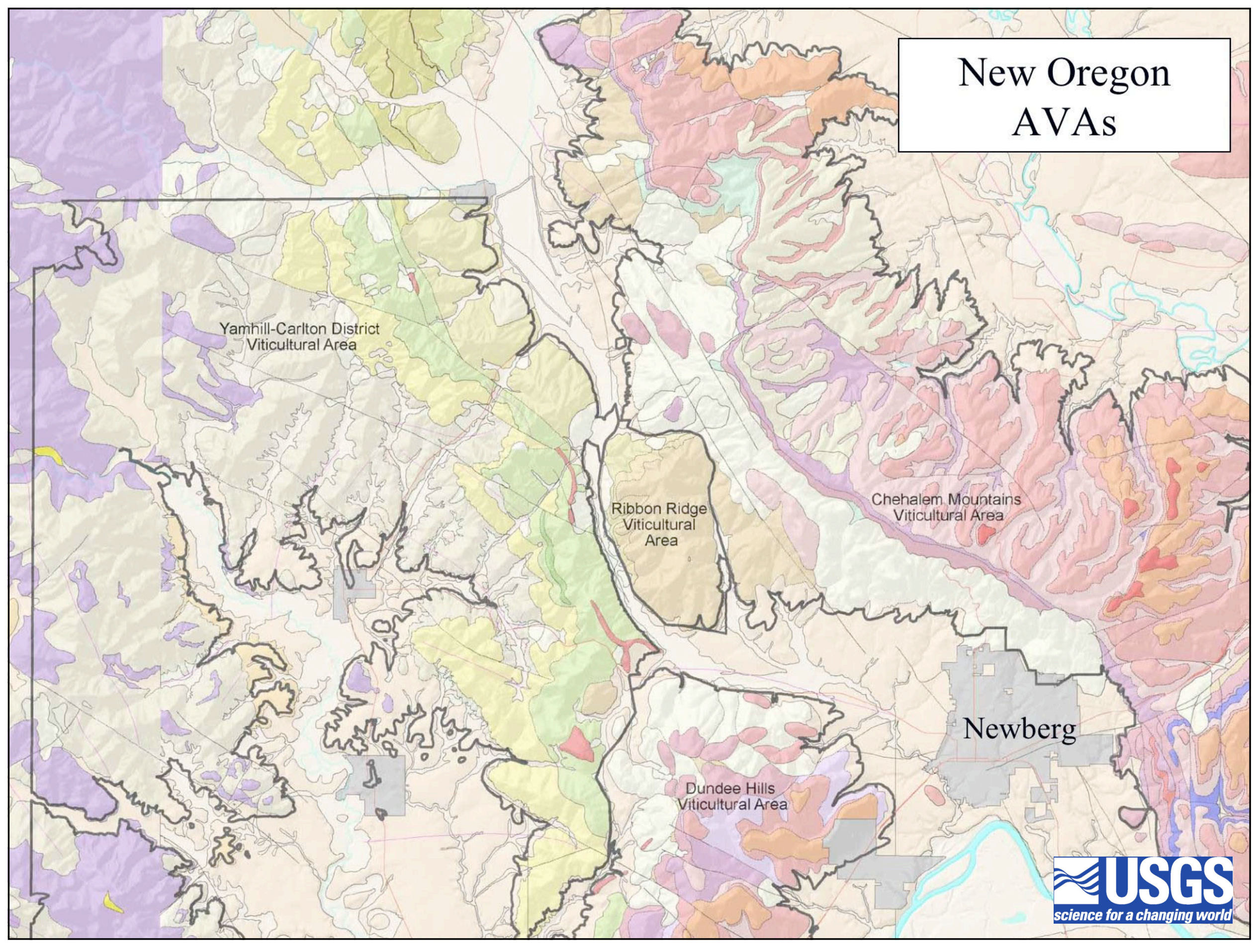




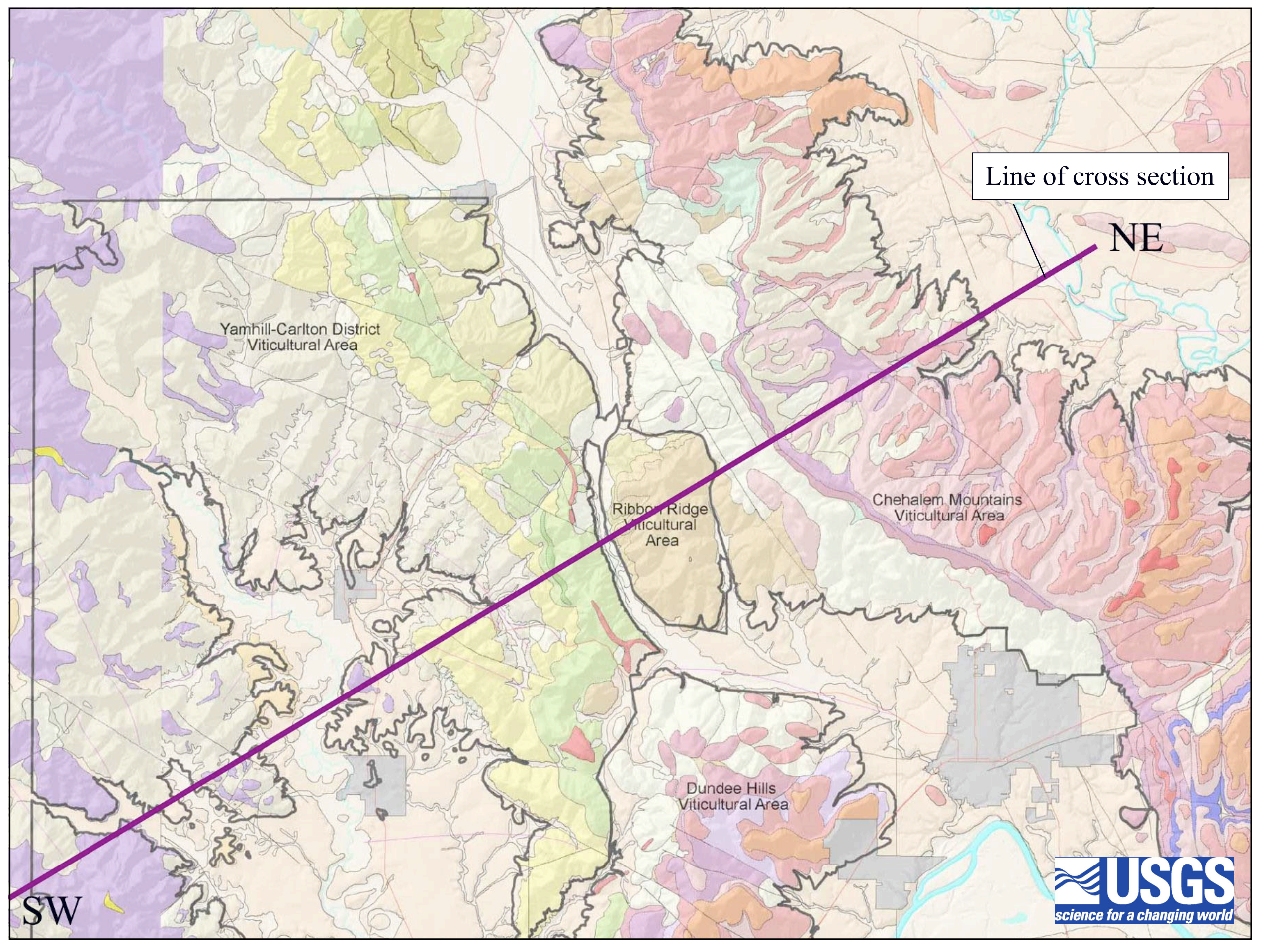




\section{Mountains are held up by basalt. Sandstone and siltstone underlie lower ridges and valleys.}

SW

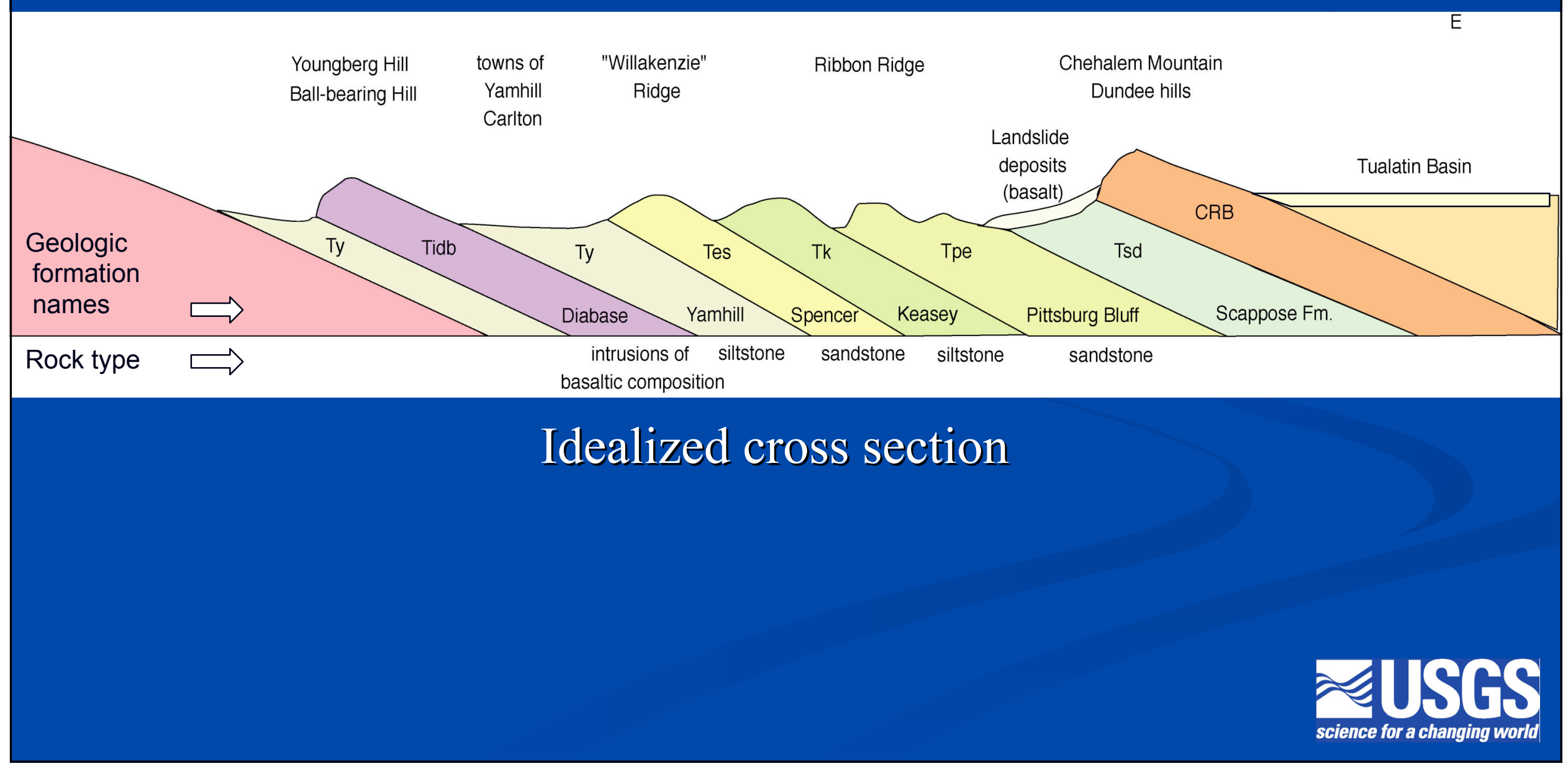




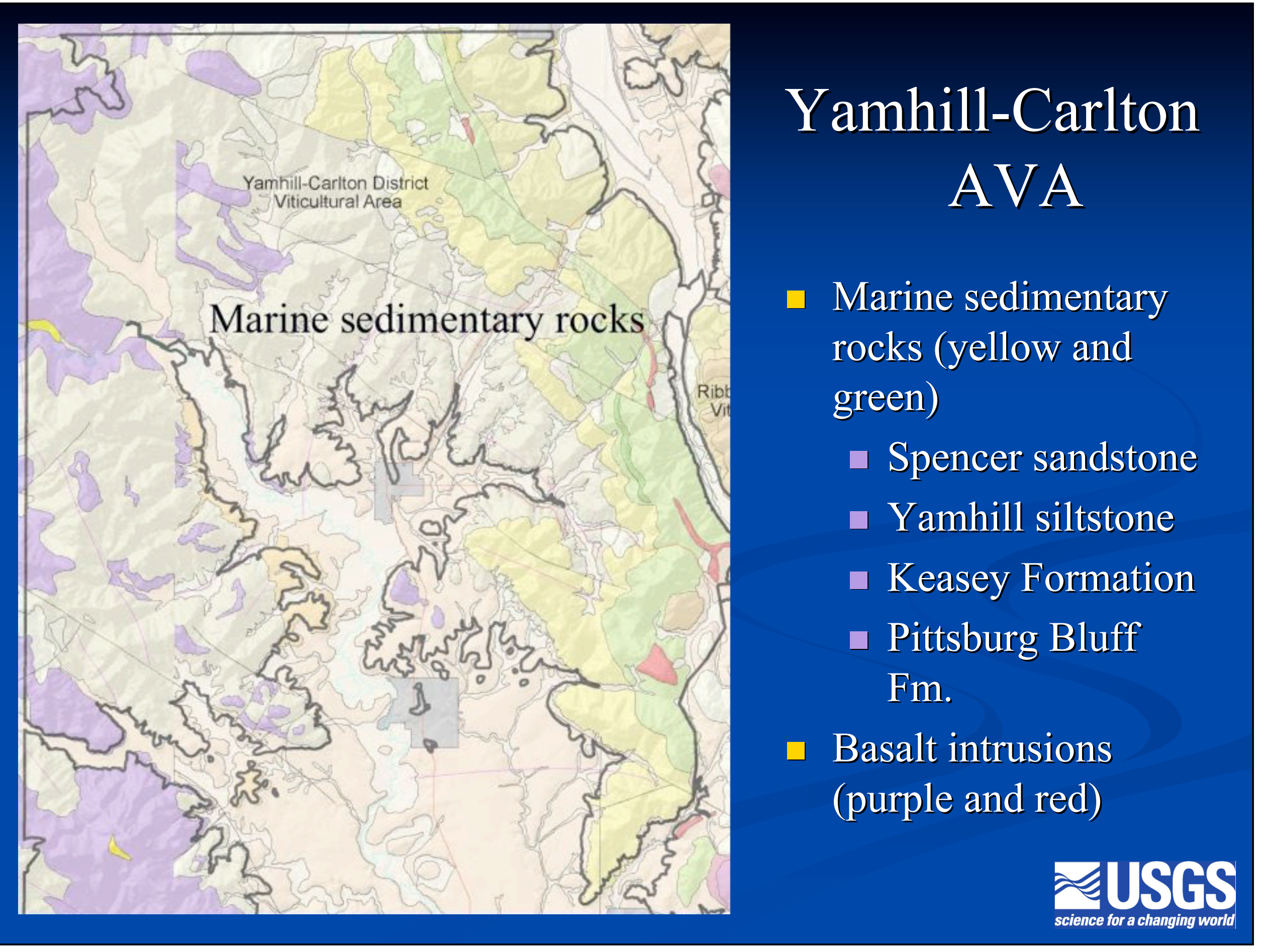




\section{Diabase (coarse-grained basalt intrusion) holds up many hills in Yamhill-Carlton- McMinnville area}

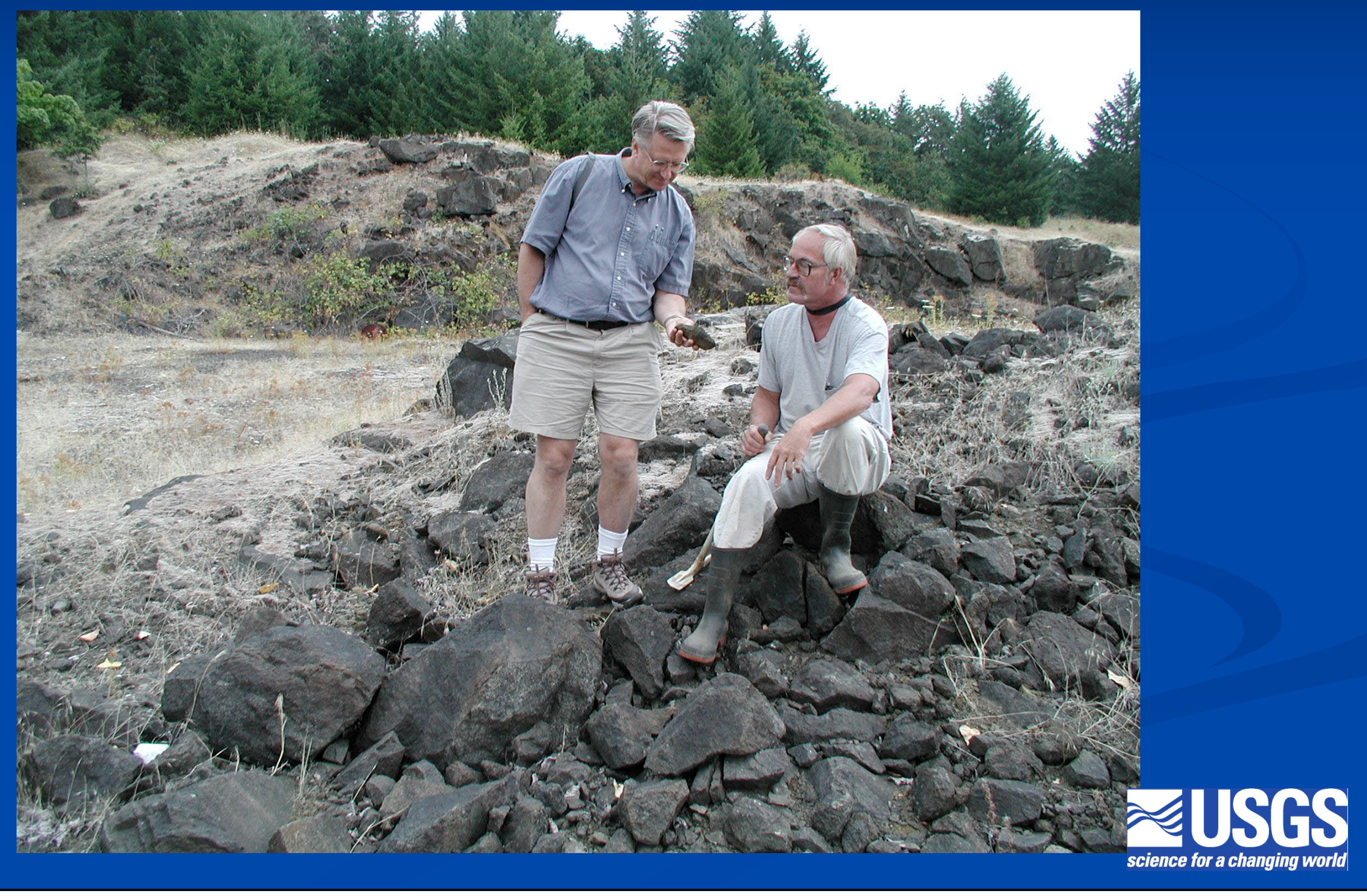




\section{Yamhill-Carlton}

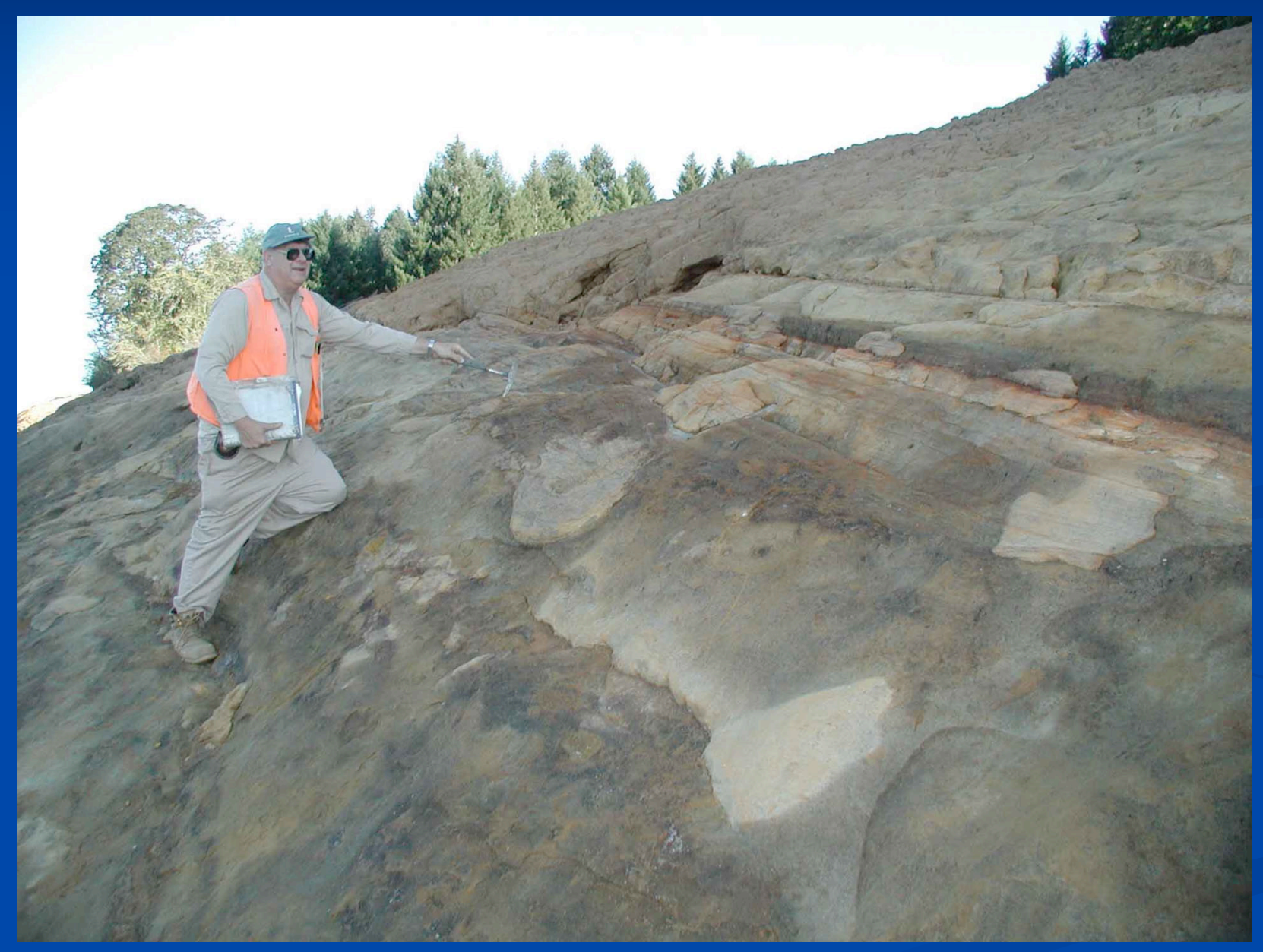

- Spencer Formation sandstone

- Underlies "Willakenzie Ridge"

Well-exposed Spencer Formation sandstone at Hagg Lake 


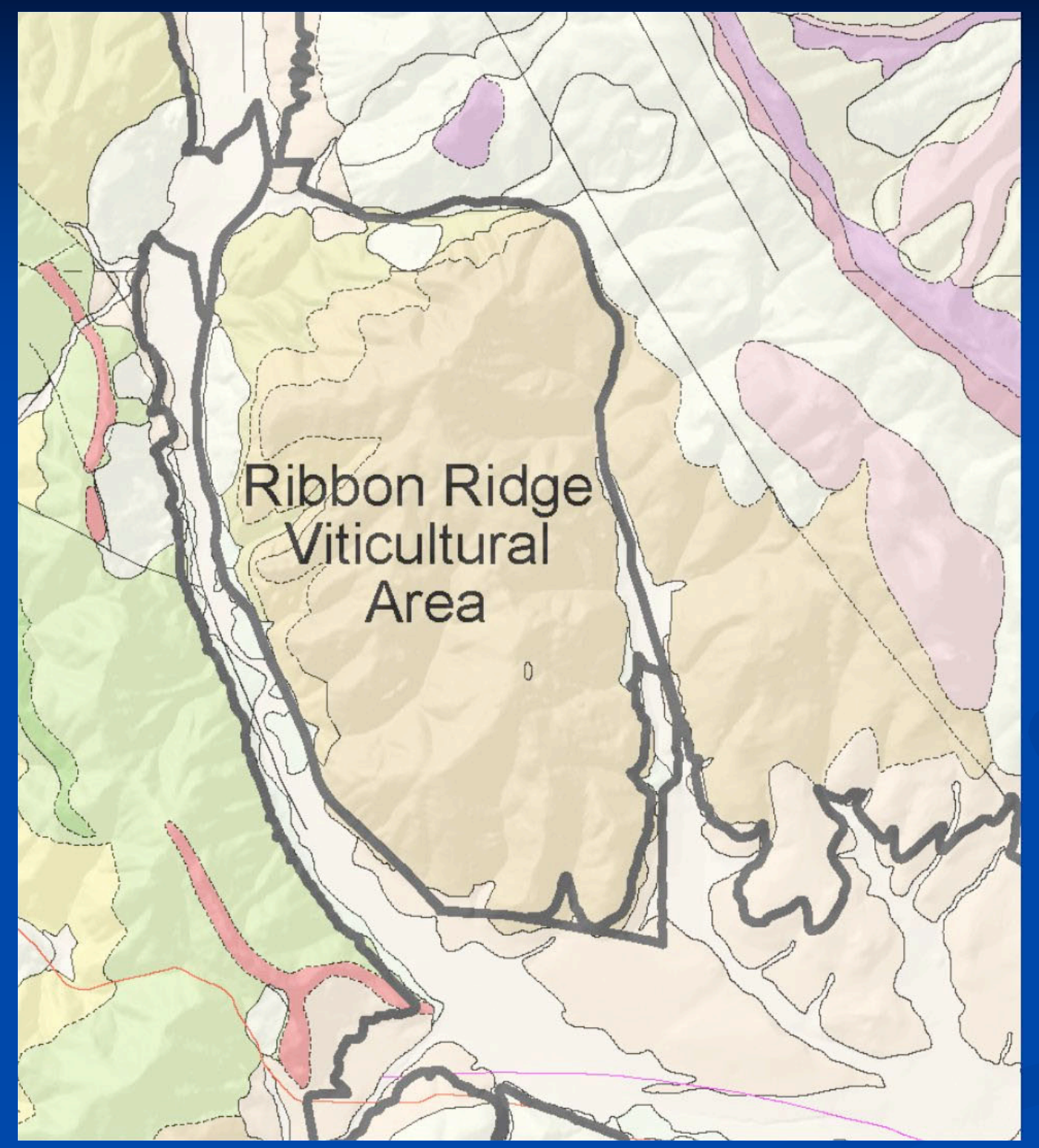

\section{Ribbon Ridge}

\section{AVA}

- Pittsburg Bluff

Formation

- Marine fine sandstone, siltstone, and mudstone

- Volcanic tuff beds from Cascade arc 


\section{Ribbon Ridge}

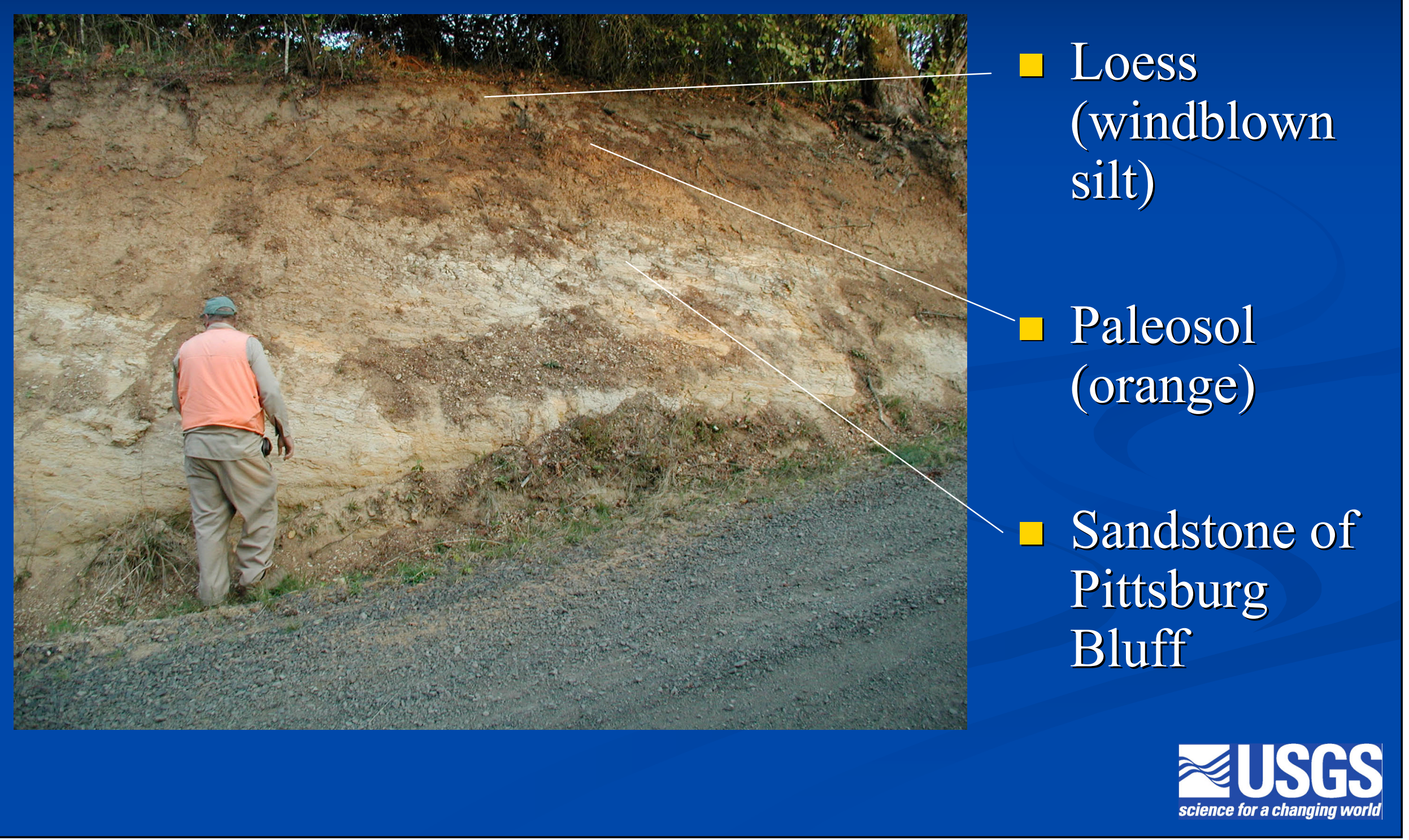




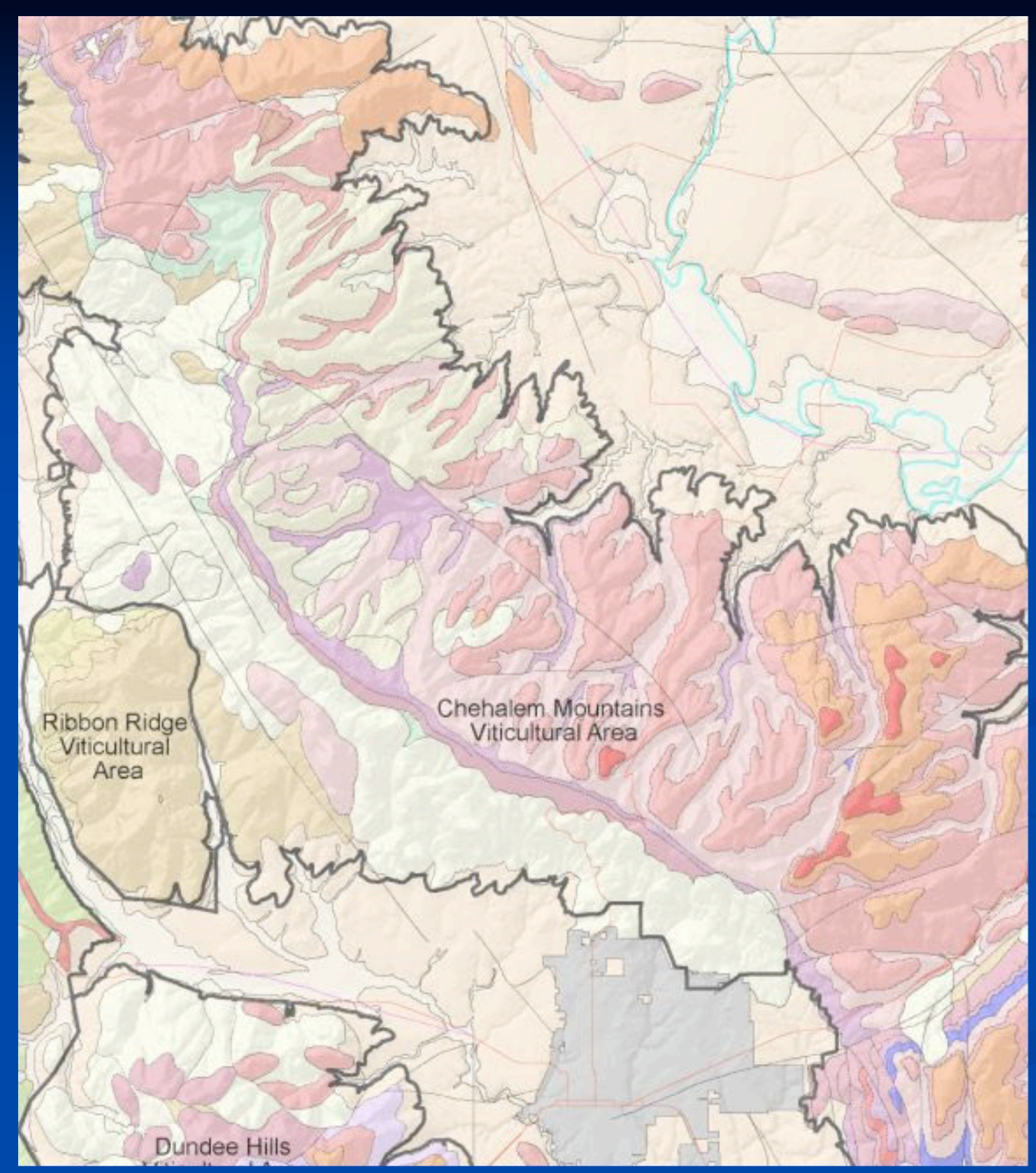

\section{Chehalem Mountains AVA}

- Columbia River Basalt

- Loess cap

- Slide bench of basalt on SW side

- Pittsburg Bluff marine sedimentary rock down low on west side. 


\section{Flow by flow stratigraphy of the CRB}

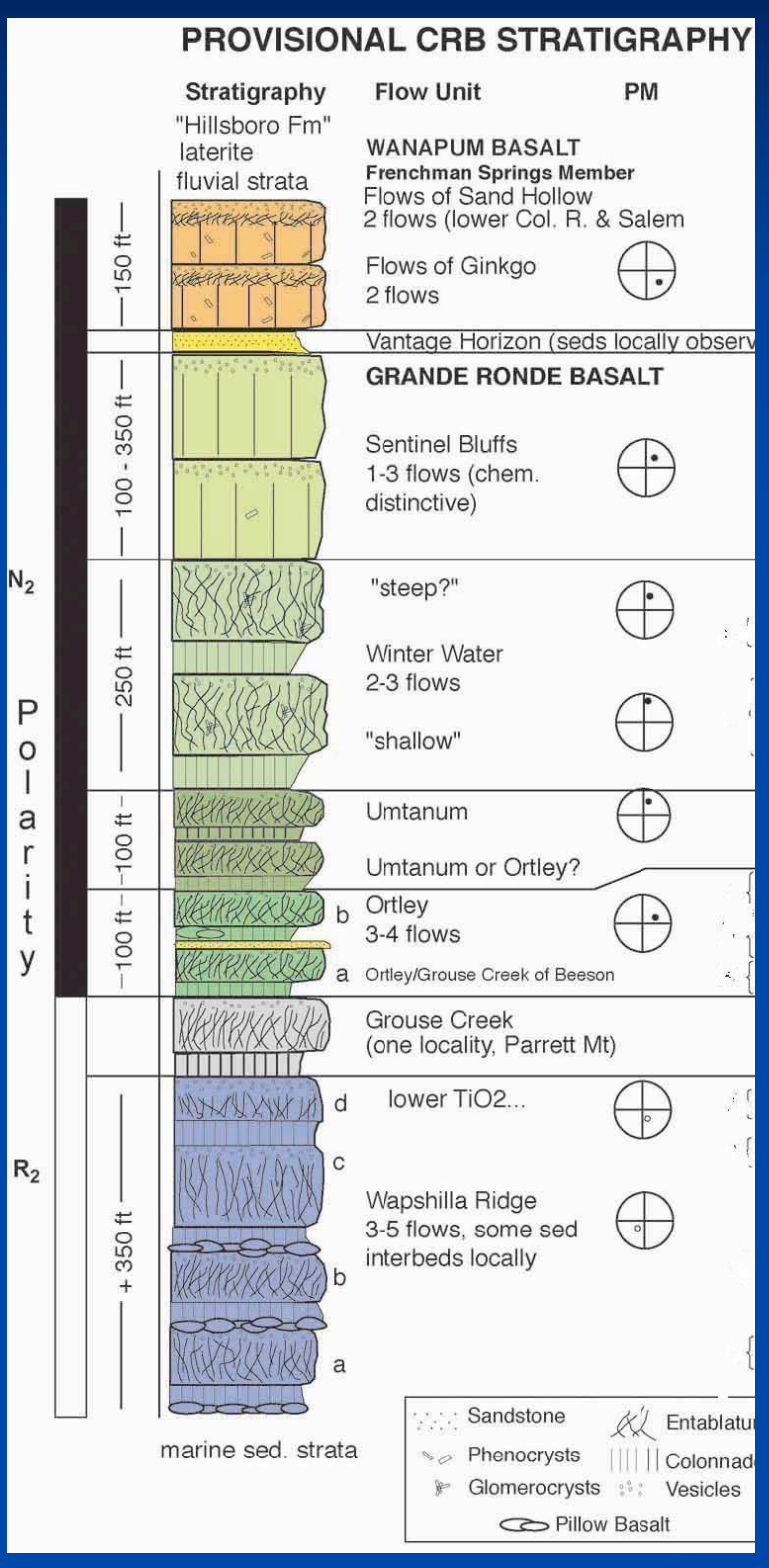

- Individual flows of CRB can be recognized with chemistry, physical appearance, and paleomagnetism. 


\section{Chehalem Mountains}

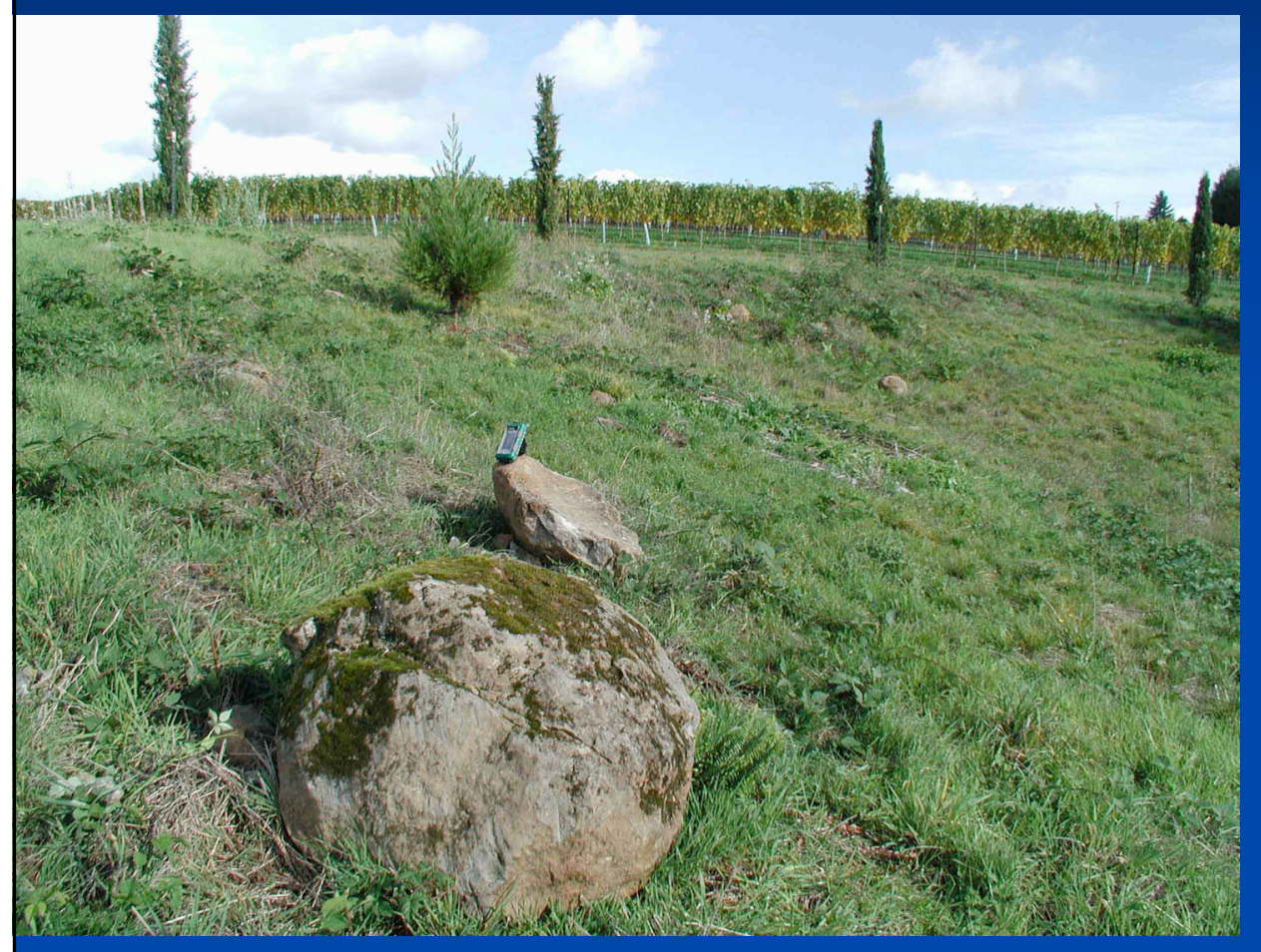

- Columbia River Basalt (CRB)

- Sentinel Bluffs Mbr. of Grande Ronde Basalt

- Loess (wind-blown silt) over Jory-like paleosol on CRB

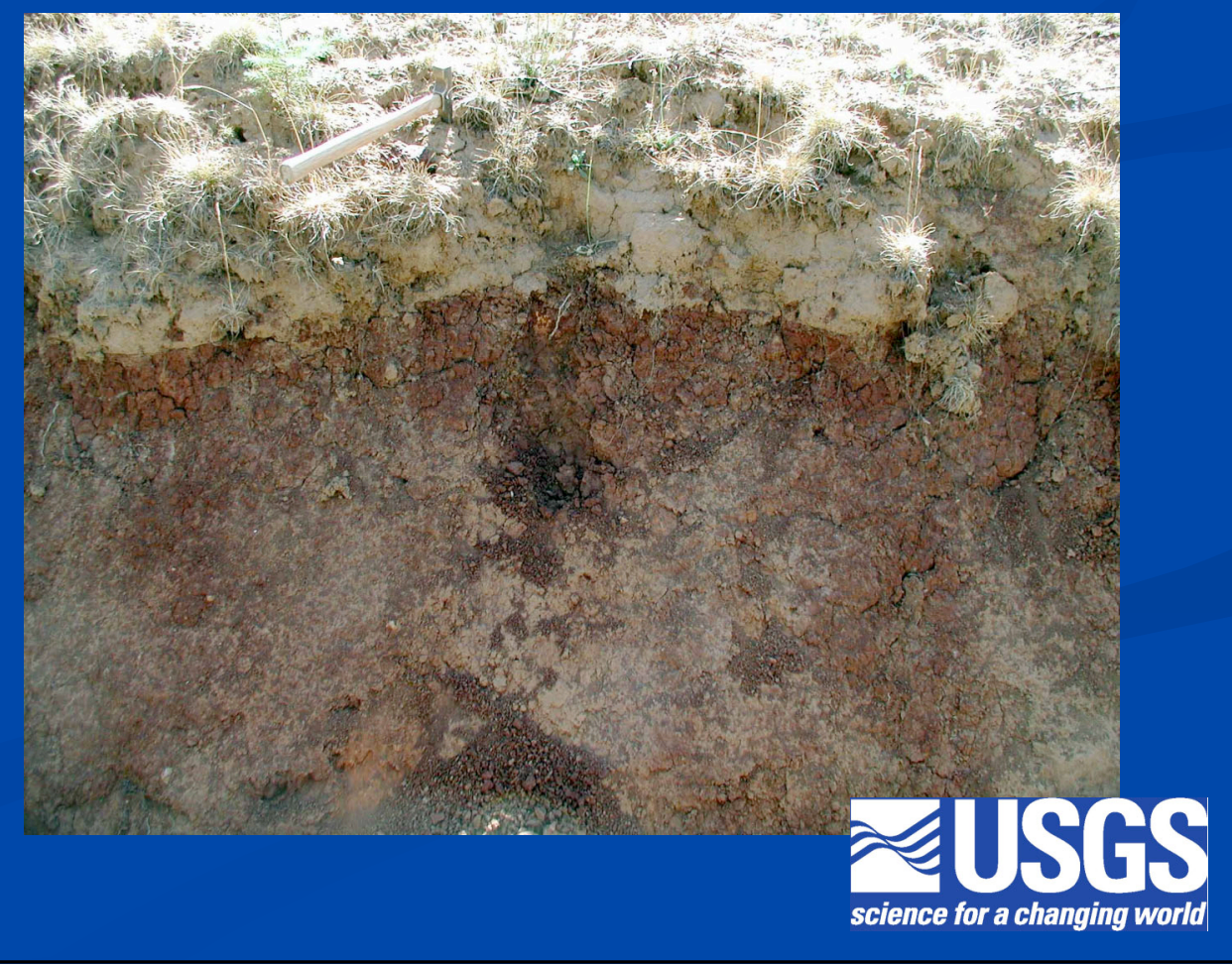




\section{Dundee Hills AVA}

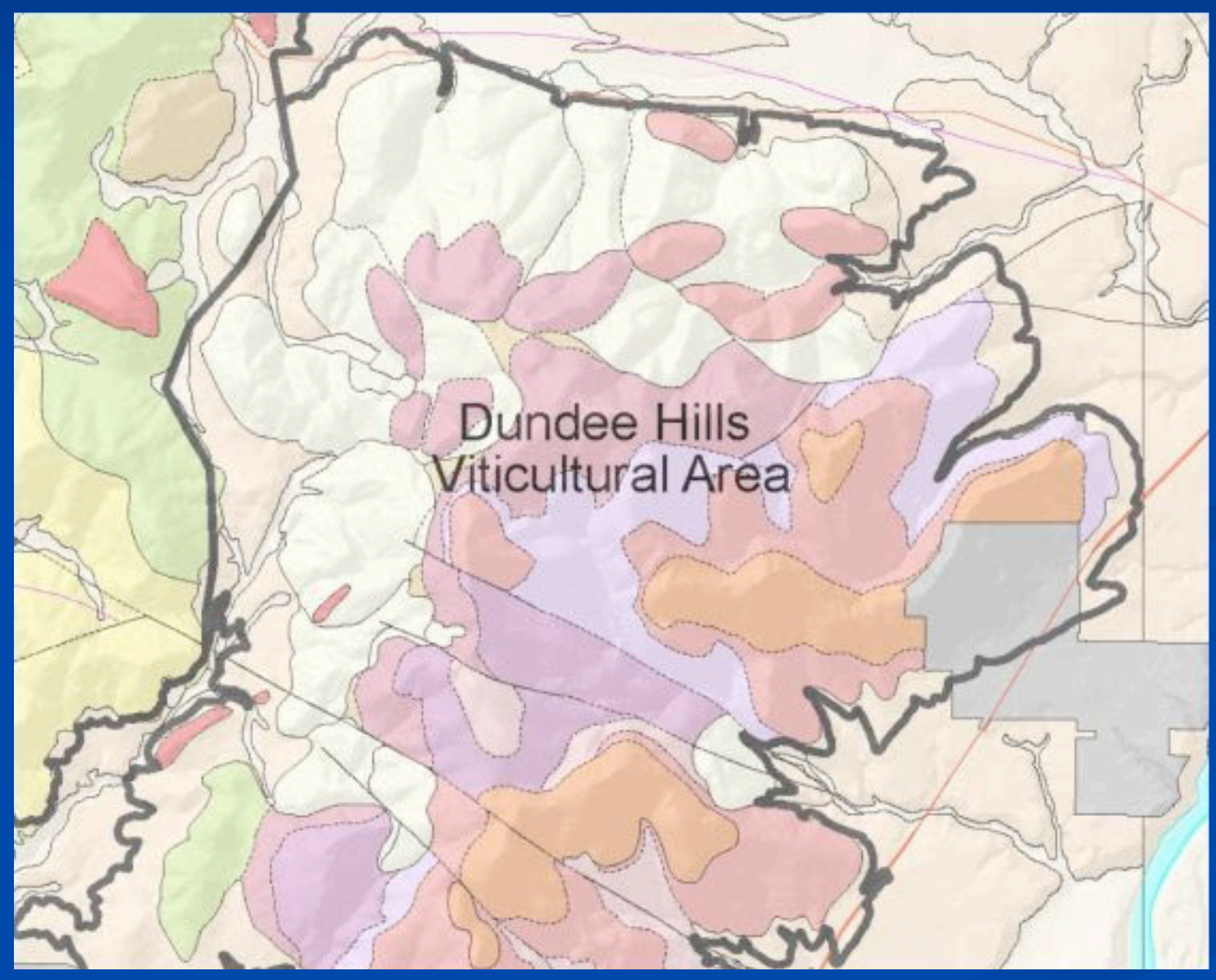

- Mostly Columbia

River Basalt

- Frenchman Springs Member

- Grande RondeSentinel Bluffs Mbr

- Grande RondeWinter Water/Ortley/ Wapshilla flows

- Landslide bench on $\mathrm{N}$ and $\mathrm{W}$ 


\section{Dundee Hills}

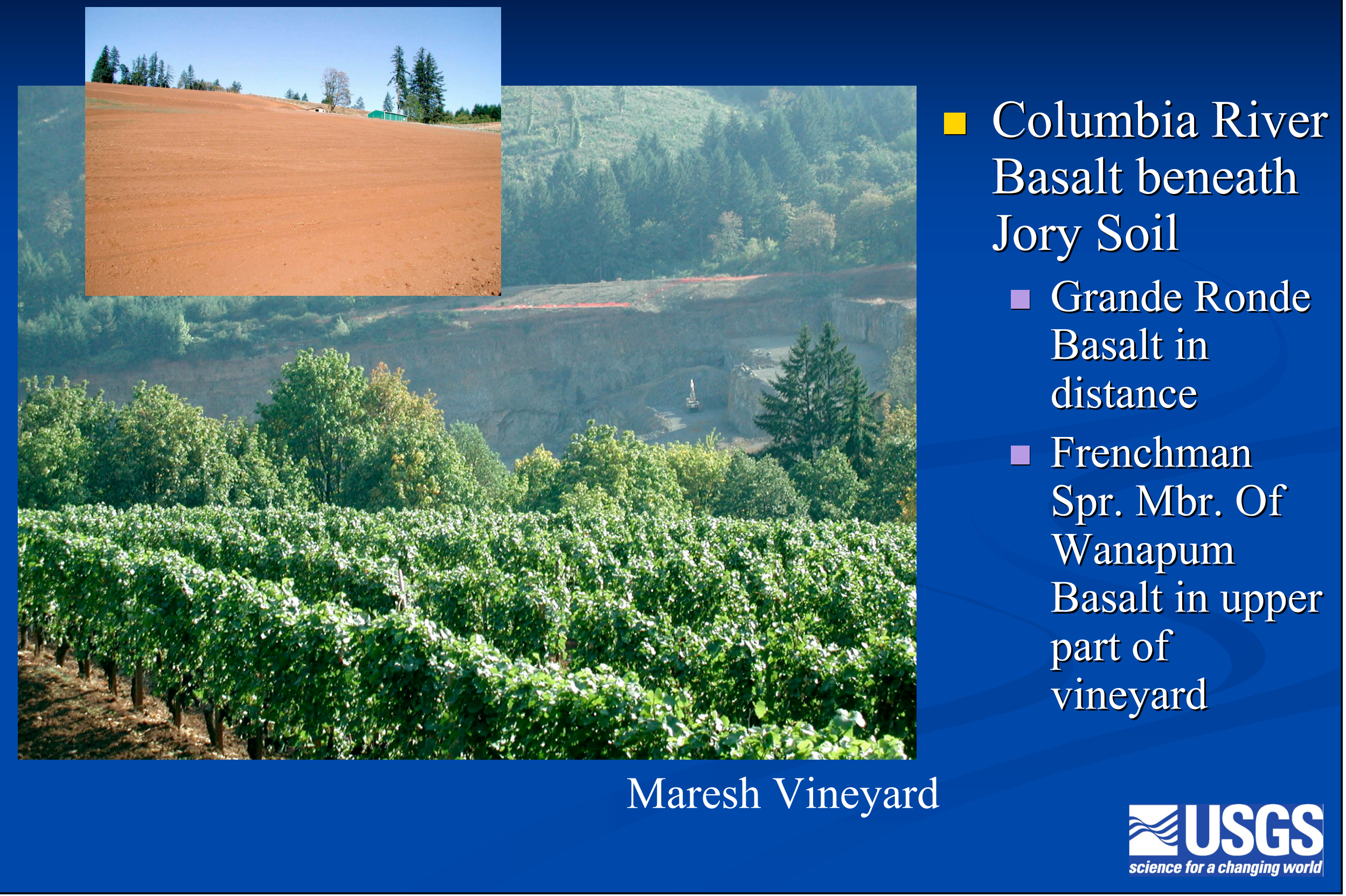




\section{What is the take away?}

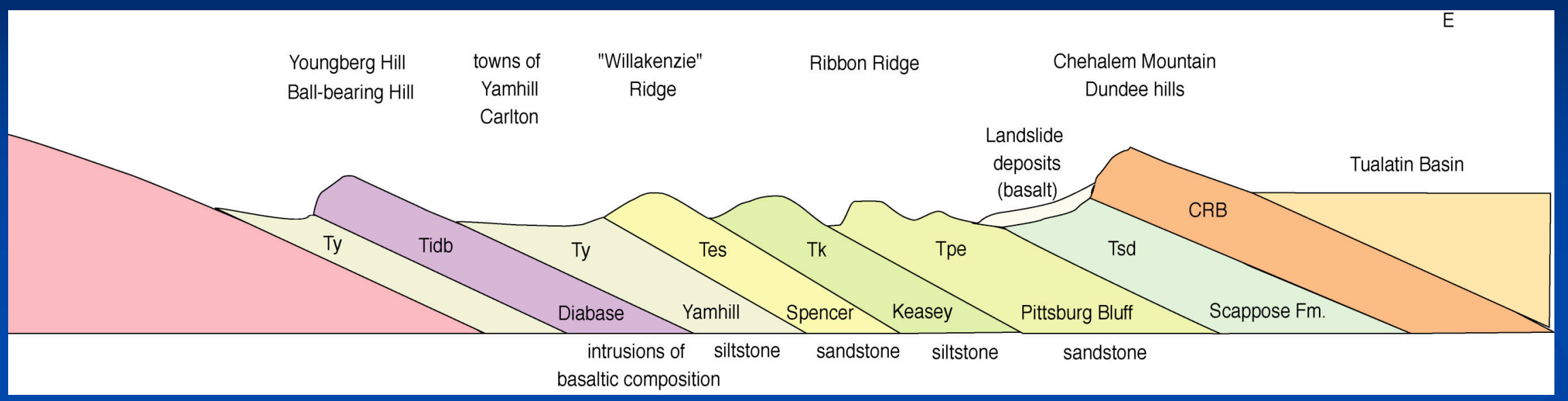

- From the Rogue to the Tualatin, each hillside has a story.

- Geology provides the landscape, its interaction with the sun and water, and the parent materials for the soils...

- And it holds up the vineyards! 